\title{
The long-term economic effects of polio: Evidence from the introduction of the polio vaccine to Sweden in 1957
}

Luis Serratos-Sotelo, Tommy Bengtsson and Anton Nilsson

The self-archived postprint version of this journal article is available at Linköping University Institutional Repository (DiVA):

http://urn.kb.se/resolve?urn=urn:nbn:se:liu:diva-182142

N.B.: When citing this work, cite the original publication.

Serratos-Sotelo, L., Bengtsson, T., Nilsson, A., (2019), The long-term economic effects of polio: Evidence from the introduction of the polio vaccine to Sweden in 1957, Economics and Human Biology, 35, 32-41. https://doi.org/10.1016/j.ehb.2019.04.002

Original publication available at:

https://doi.org/10.1016/j.ehb.2019.04.002

Copyright: Elsevier

http://www.elsevier.com/

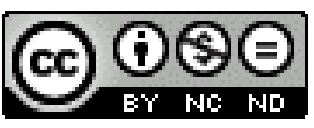




\title{
The Long-Term Economic Effects of Polio: Evidence from the Introduction of the Polio Vaccine to Sweden in $1957^{*}$
}

\author{
Luis Serratos-Sotelo $^{\dagger 1,2,3}$, Tommy Bengtsson ${ }^{1,2}$, and Anton Nilsson ${ }^{2,4}$ \\ ${ }^{1}$ Department of Economic History, Lund University \\ ${ }^{2}$ Centre for Economic Demography, Lund University \\ ${ }^{3}$ Max Planck Institute for Demographic Research \\ ${ }^{4}$ Division of Occupational and Environmental Medicine, Lund University
}

\begin{abstract}
This study explores the impact an exogenous improvement in childhood health has on later-life outcomes. Using extensive and detailed register data from the Swedish Interdisciplinary Panel covering up to 2011, we follow individuals exposed to the introduction of the first vaccine against polio in Sweden (birth cohorts 1937-1966) until adulthood in order to quantify the causal effect of polio vaccination on long-term economic outcomes. The results show that, contrary to what has been found in the literature for other health-related interventions, including other vaccines, exposure to the vaccine against polio did not seem to have any long-term effects on the studied adult economic outcomes. Upon closer inspection of how the disease affects children, this might be explained by the fact that no scarring effects from exposure to high incidence of polio were found on adult income, educational achievement, or hospitalizations, which seems to suggest that those who contracted the illness but suffered only the milder symptoms of the disease made a full recovery and had no lifelong sequels as a consequence of the condition. The absence of scarring effects is hypothesized to be related to the pathology and epidemiology of the disease itself, which infects many, but scars only those who suffer the most recognizable paralytic symptoms.
\end{abstract}

Keywords: vaccine, polio, income, education, early-life, Sweden

${ }^{*}$ This is an Accepted Mansucript. Published as Serratos-Sotelo, L., Bengtsson, T., Nilsson, A. (2019). The longterm economic effects of polio: Evidence from the introduction of the polio vaccine to Sweden in 1957. Economics Human Biology, 35, 32-41. See Full Article at https://doi.org/10.1016/j.ehb.2019.04.002. This work is licensed under the Creative Commons Attribution-NonCommercial-NoDerivatives 4.0 International License. To view a copy of this license, visit http://creativecommons.org/licenses/by-nc-nd/4.0/ or send a letter to Creative Commons, PO Box 1866, Mountain View, CA 94042, USA.

${ }^{\dagger}$ Corresponding Author luis.serratos@ekh.lu.se. The authors gratefully acknowledge suggestions and comments from Mikko Myrskylä, Peter Eibich, Martin Dribe, Martin Önnerfors, Kirk Scott, Siddartha Aradhya, Volha Lazuka, Luciana Quaranta, Kris Inwood, and Rowena Gray. Max Meza-Azzario provided helpful assistance with data digitization. This paper greatly benefited from comments from attendants to the UC3M Inter-University PhD Workshop in Economic History (May 2017), the Uppsala University Health Economics Workshop on Natural Experiments (June 2017), the Seminar in Economic Demography at Lund University (October 2017), the 42nd Annual Meeting of the Social Science History Association (November 2017), and the Laboratory on Population Health at the Max Planck Institute for Demographic Research (December 2017). Financial support for this study from Stiftelsen för Främjande av Ekonomisk Forskning vid Lunds Universitet, the Department of Economic History (Lund University), and the Max Planck Institute for Demographic Research is gratefully acknowledged. 


\section{Introduction}

The development of vaccination is one of the medical innovations that has saved more human lives in history through prevention, rather than through treatment, of illnes: ${ }^{1}$ Before vaccines became safe and widespread, multiple epidemic diseases decimated entire populations at will, to the point where pandemics were a common and ever-present threat and everyone, from the richest to the poorest, was subject to the same probability of falling victim to one of this diseases ${ }^{2}$

Polio was a recurrent epidemic in Sweden at the beginning of the 20th century, and could leave affected children with life-long limitations such as paralysis. It wasn't until well into the 20th century when medical innovations made a vaccine available. The immediate benefits of the vaccine were noticeable in the dropping number of cases and the virtual eradication of the disease from the country in less than 10 years. However, the literature on long-term effects of this vaccination is scarce, and the impact of early-life health interventions on later-life outcomes remains for the most part unexplored.

This paper, thus, exploits the plausibly exogenous variation in early-life health consequence of the sharp introduction of polio immunization in Sweden during 1957. It employs methods of causal inference, specifically a variation on the classical differences-in-differences model, to disentangle the complicated relationships and go beyond correlations to address the potential causal effect of the vaccine on adult outcomes. The main working hypothesis is that exposure to the vaccine caused an improvement in early-life health, which would be later translated into increased adult human capital and this would, in turn have measurable effects on adult economic outcomes. Furthermore, since the disease affected differently across the regions of the country, it is expected that those in a worse situation had, in principle, more to gain from the vaccination and eradication campaign. Consequently, the scope of this paper is to analyze if there were systematic differences in income and education among those exposed to the vaccine across the differently-affected regions of Sweden. It also goes beyond the usual economic outcomes by including a measure of long-term health: the number of hospitalizations during adulthood.

The data for this study comes from two sources, polio incidence data was obtained from yearly statistical books on population and public health published by Statistics Sweden (1911-1970), while the individual-level data was obtained from the Swedish Interdisciplinary Panel, which provides register data for the population of Sweden for the period 1968-2011, including information on income, education, and health. The cohorts included in this study are those born in Sweden between 1937 and 1966.

The results suggest that, contrary to other early-life health interventions in the literature, the vaccine against polio did not have a significantly different effect on the outcomes of those children who were exposed to it in high-incidence regions of Sweden, compared to those vaccinated in low-incidence regions. This uniform effect of the vaccine regardless of pre-treatment incidence rate suggests that exposure to an outbreak of polio, given that the individual avoids the paralytic symptoms of the disease, does not have a long term impact on a person's later-life outcomes (often referred to as scarring).

The rest of this paper is structured as follows. Section 2 provides the context of disease, the

\footnotetext{
${ }^{1}$ It would probably rank second or third only behind the popularization of germ theory and the introduction of clean water and sewage. Godlee (2007) included all three in the BMJ's 2007 list of Medical Milestones since 1840

${ }^{2}$ One study, for the Swedish case, finds that, for instance, mortality gradients among ages and social classes emerged only as late as 1950 (Bengtsson and Dribe, 2011)
} 
vaccine, and the country during the time period of interest; section 3 reviews the relevant related literature; section 4 delineates the methodological empirical approach; section 5 describes the data which was used for the study; section 6 presents the results, while section 7 presents a discussion on the results and concludes.

\section{Context}

Acute Poliomyelitis (often referred to as Polio, for short) is an extremely contagious disease consequence of a viral infection to the nervous system. The name itself evolved during the years to reflect the scientific community's knowledge of the disease, from the rudimentary "debility of the lower extremities" to the more complicated "Poliomyelitis Acuta" which is a mixture of Greek and Latin words meaning "inflammation of the gray matter" (Paul, 1971). The virus responsible, poliovirus, is known to have three different types, all of which can lead to the infection and the disease, although acquired immunity is generally considered to be homotypic (Nathanson and Martin, 1979). After initial hypotheses about air-transmission of the virus, it was found that it mostly passes from human to human via the oral-fecal route or through contaminated food or water. Once the virus enters the body and multiplies in the digestive tract one of two scenarios will develop, either the individual's immune system will fight it and stop the spread of the virus, giving the person a lifelong immunity (often called inapparent infections), or the immune response will not be enough and the virus will continue to multiply and attack the nervous system, specifically the gray matter of the spinal cord. Cases in which the latter scenario develops will usually result in some degree of muscular weakness or paralysis, since muscles rely on the motor nerve supply of the spinal cord to function. Given that motor nerve cells cannot regenerate themselves, established paralysis is considered permanent (Paul, 1971).

Epidemiologically, the disease spreads with extreme ease among susceptible individuals with inapparent infections being the majority of cases. Among this kind of infections the symptoms are usually mild, including a cold-like fever, which are easily overlooked as they relate to so many other immune responses. A consequence of this is that a majority of people who were ever infected with polio did not even notice it and were never diagnosed. It is estimated that only 1 in every 200 infections resulted in apparent infections and some degree of irreversible paralysi: ${ }^{3}$ This paralysis can range from mild to severe, as it progresses up from the limbs, and among those paralytic cases, between 5-10\% resulted in death due to the eventual reach of the paralysis to the diaphragm, the muscle that allows unassisted breathing $4^{4}$. No treatment for the disease is known. Only prevention through vaccination has proved effective in modern global eradication efforts (World-Health-Organization, 2017).

According to the World-Health-Organization (2017), the population most at risk of contracting the disease nowadays are those under the age of 5 . While this might be the case for modern societies, the conditions and disease dynamics in Sweden at the beginning of the 20th century might be

\footnotetext{
${ }^{3}$ To put these numbers in perspective, let's look at Sweden's 1912 outbreak, where doctors around the country reported 4,112 cases of paralytic polio. This means that, according to the infection-to-paralysis ratio, there were actually around 820,000 Swedes who contracted the virus, or $15 \%$ of the country's total population on that year. While the most acute consequences of the disease were relatively rare, the infection was common and widespread, and the milder symptoms affected a considerable proportion of the population.

${ }^{4}$ The rate of paralytic infections to total infections, and of deaths to paralytic infections means that the death rate from total infections of polio was around 0.02-0.05\%. Given these low numbers, we don't think that mortality could be a possible source of selection (through a "healthy survivor" effect) in our statistical analysis.
} 
different. Axelsson (2004) argues, in a detailed and historical study of the disease in Sweden, that the bulk of infections happened before the age of 10, with those under 5 having indeed a greater risk but only after this later age was the incidence of the disease low enough that it could be considered a rare occurrenct5

The disease appeared in Sweden in 1881 and, since the beginning of the 20th century, poliomyelitis became an annual feature in the epidemiological reports, where it took its name from its most recognizable consequence: infantile paralysis (barnförlamning in Swedish). Although the disease began being included in the statistical reports in 1905, it did so under the category of nerve disease. It was only later that it was assigned to the category of infectious disease, following the big epidemics of the first decade of the 1900's that saw thousands of registered cases occur all across the country Axelsson, 2004, p. 46). As to why the disease passed from an endemic state to become suddenly epidemic, the case has been made that polio has always been present in human settlements, with infants and children becoming exposed to the virus while still enjoying maternal immunity protection (Zinkernagel, 2001). This resulted in small exposures during childhood and in some sort of natural immunity to polio via repeated contact with the wild virus. However, as sanitation and water systems made adequate everyday hygiene less of a seldom-occurring phenomenon 6 this early-exposure to poliovirus disappeared, and individuals were left without their natural protection against the disease (Axelsson, 2009, Smallman-Raynor and Cliff, 2006).

Figure 1 shows the national incidence rate for the disease in the period 1910-1966. As can be seen in the graph, the history of the disease is one of sudden epidemic outbreaks, with years like 1911, 1912, 1937, 1945, 1950, and 1953 experiencing particularly high incidence rates, which translate roughly to around 2,000-5,000 cases in a single year, out of a population of around 5-6 million individuals. At the time of the introduction of the vaccine against polio (1957, dotted line) the country was just coming out of the second worst outbreak in its history (1953), and while the rate of incidence naturally declined after each outbreak, it would be imprudent to assume, as is common belief in the anti-vaccination movement, that the disease was already "dying out" and that the observed reduction in the epidemic is coincidental instead of causal. At no point after the 1953 epidemic and before the introduction of the vaccine was the incidence rate lower than in some years during the 1920s and 1930s, none of which resulted in the natural elimination of the disease.

Given the regular outbreaks of polio that happened all across the globe, international efforts to find a vaccine were considerable. Research conducted by Enders, Weller and Robbins allowed for growth of poliovirus in different types of tissue, including non-nervous one (which ultimately earned them the Nobel Prize in Medicine in 1954); this knowledge and ability contributed to the work of Jonas Salk and Albert Sabin. Salk worked on the development of an inactivated, or killed, vaccine (IPV), which consisted in killed cells of the virus injected intramuscularly and was released to the public in 1955, while Sabin developed a weakened, or live, vaccine (OPV) which, due to the presence of live virus could be administered orally in a safe manner and was ready for use in 1961 (Gothefors, 2008). These two vaccines are thought to be responsible for the elimination of wild poliovirus from most of the world, and they continue to be vital weapons to prevent the disease in areas where it

\footnotetext{
${ }^{5}$ Indeed, one of the first studies of the disease, conducted by Dr. Karl Medin in Sweden during the late nineteenth century, was focused on the study of symptoms and afflictions of "school-age children" (Paul 1971) which suggests that children between the ages of 6 and 10 were also part of the population most at risk.

${ }^{6}$ A study for the Swedish case found that introduction of public water and sewerage systems began in 1875 and was associated with reduced mortality from water borne diseases (Helgertz and Önnerfors, 2019)
} 
Figure 1: National Incidence Rate of Acute Poliomyelitis: Sweden, 1910-1970 (per 10,000 inhabitants).

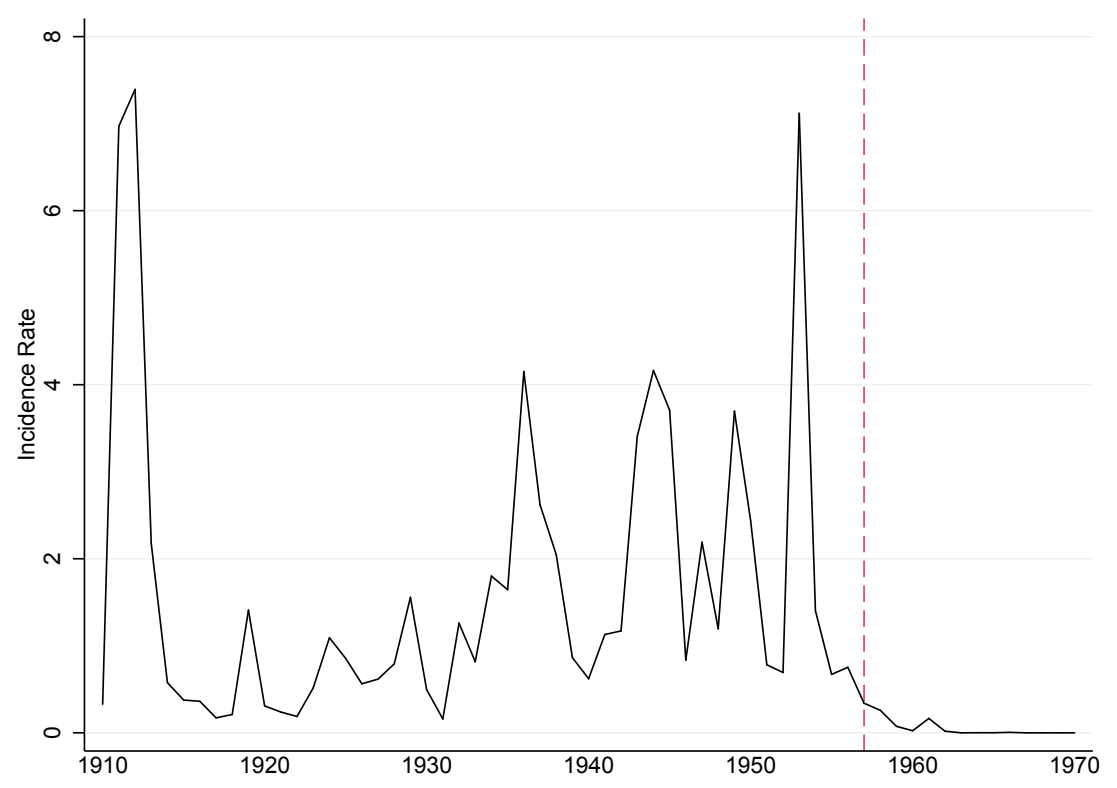

Source: Author's calculations with data from Statistiska Centralbyrån.

Note: The red dotted line marks the introduction of the vaccine against polio in Sweden (1957). Major outbreaks of the disease occurred in 1911-12, 1936-37, 1943-45, 1949-50, and 1953.

persists to be endemic. (World-Health-Organization and others, 2017)

In Sweden, a group of scientists presented their independently developed inactivated vaccine in Wesslén et al. (1957), and while the country started a public health vaccination initiative that same year using both the Salk and Swedish vaccine, since 1958 the country has used exclusively the locally developed vaccine produced at the National Bacteriological Laboratory in Stockholm. (Fagraeus and Böttiger, 1980). Figure 2 shows the average incidence rate of polio in all the counties (län) of Sweden in the years before the introduction of the vaccine in 1957. As can be appreciated in the map, the counties of Sweden all had different incidence rates of the disease, with Södermanland and Gotland being the areas where polio was more common. After the introduction of the vaccine, it took less than ten years to achieve elimination of the wild virus from the country, thanks to almost universal vaccination (Fagraeus and Böttiger 1980), and by 1967 it stopped being featured in the public health statistical reports produced annually by Statistics Sweden due to eradication 7 (Statistiska Centralbyrån, 1911a).

\section{Related Literature}

This paper is related to a number of research areas and previous literature. First, to the pioneering works of Grossman (1972) Becker (1964) and Mincer (1974), who first developed, in economics, the concept of measurable human capital, expanding it later to include investments made in health and education, and then carried out the first measurements of the relationship they have with an individ-

\footnotetext{
${ }^{7}$ The last case where poliovirus was isolated from a Swede happened in 1962, a mere 5 years after the introduction of the vaccine (Fagraeus and Böttiger, 1980)
} 
Figure 2: Average Incidence Rates (per 10,000 inhabitants) of Acute Poliomyelitis by Swedish Counties 1952-1956.

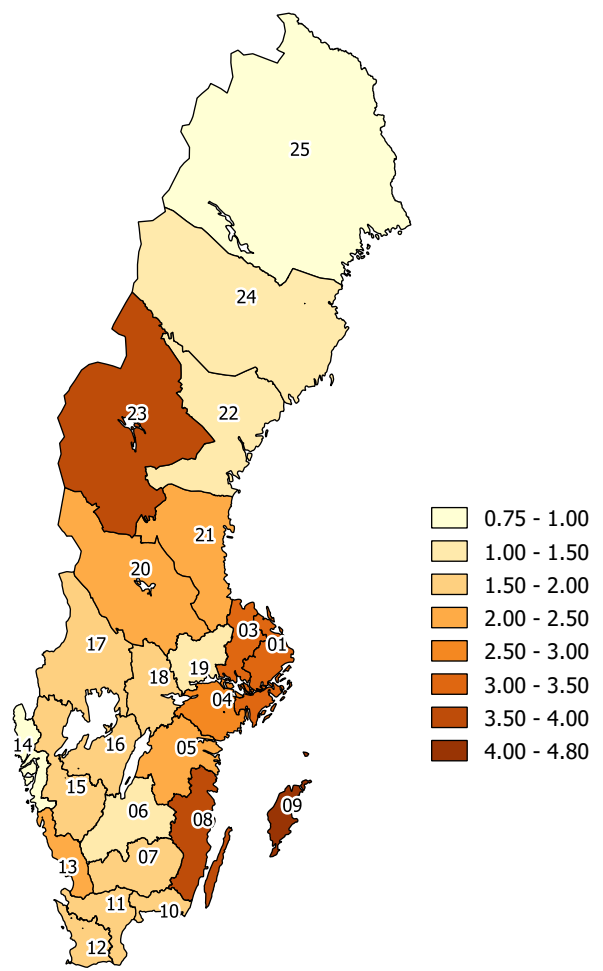

Note: The numbers over the map are the official county codes from Statistics Sweden and correspond as follows: 01 Stockholm Län (including Stockholm Stad), 03 Uppsala Län, 04 Södermanlands Län, 05 Östergötlands Län, 06 Jönköpings Län, 07 Kronobergs Län, 08 Kalmar Län, 09 Gotlands Län, 10 Blekinge Län, 11 Kristianstads Län, 12 Malmöhus Län, 13 Hallands Län, 14 Göteborgs och Bohus Län, 15 Älvsborgs Län, 16 Skaraborgs Län, 17 Värmlands Län, 18 Örebro Län, 19 Västmanlands Län, 20 Kopparbergs Län, 21 Gävleborgs Län, 22 Västernorrlands Län, 23 Jämtlands Län, 24 Västerbottens Län, 25 Norrbottens Län.

Source: Author's calculations with data from Statistiska Centralbyrån.

ual marginal productivity in the labor force (a.k.a. a person's wages.)

Secondly, it is also related to the literature that explores the impact of early-life conditions on later-life outcomes. Barker (1990) was the first to link adverse conditions during the gestational period to worse adult health. He found out that in utero conditions affect weight at birth, which in turn is a good predictor of adult cardiovascular diseases. His research suggests that conditions in utero, infancy, and early childhood are of vital importance for later-life outcomes, since they affect the process of health capital formation in an age where vital gains are usually made 8

Fogel and Costa (1997) combined this knowledge with historical data to find that technological and physiological improvement correlate in such a way that it has generated a form of human evolution that remains biological, while not being genetic, a phenomenon they call the technophysio evolution. It is according to both these theories (fetal origins and technophysio evolution) that a new branch of economic literature emerged, looking to identify the effects of different technological improvements on human health, as well as economic outcomes. Since then, many studies have found connections

\footnotetext{
${ }^{8}$ For a detailed review of the Fetal Origins hypothesis see Almond and Currie (2011); Almond et al. (2018)
} 
between harsh conditions in early-life and: height(Karimi and Basu, 2018), cognitive abilities during the teenage years (Chay et al. 2009), during old age (Case and Paxson, 2009), occupational choice (Bhalotra et al. 2016), and years of education (Almond, 2006, Cunha et al., 2010, Bundervoet and Fransen, 2018).

Another group of studies have extended this theory to include impacts on economic outcomes, focusing on the Swedish case and taking advantage of the abundance of historical and contemporary data. In that sense, Bengtsson and Lindström 2000, 2003) first began exploring the effects on mortality of being exposed to misery and disease early in life and found that for the Swedish case, disease load in early-life had a marked effect on later-life mortality; Bengtsson and Broström (2009) estimated that being exposed to disease in infancy had a negative impact on socioeconomic status at age 50; Quaranta (2013) found that, for Swedish women, being born in a year with a high disease load lowered the probabilities of attaining a high socioeconomic status in adulthood, while Lazuka (2018) found that being exposed to improved health care in infancy has a positive effect on individual permanent income of up to $5 \%$.

Noteworthy is the study by Gensowski et al. (2018), who study long-term outcomes among survivors of paralytic polio. Using data from Danish hospital and administrative records, they find that children hospitalized with paralytic polio during the last epidemic in Denmark (1952) grow up to have a higher probability of being in disability insurance and early retirement by age 50 than non-paralytic polio survivors. They also find that paralytic polio survivors are more likely to work in white-collar occupations than their non-paralytic counterparts, which seems to point towards compensatory behavior and selection out of physically demanding occupations. They also find no differences in wages between both groups.

Finally, this study is also related to a branch of economic literature that specializes in the evaluation of public-health interventions. These studies usually strive to find causal relations, through clever econometric design and techniques, and taking advantage of natural experiments. For instance, Bleakley (2007) studied the eradication of hookworm disease in the American south around 1910 and found that the deworming treatment lead to substantial income gains and an increase in the returns to schooling. Bleakley (2010) analyzed the eradication of malaria from Brazil, Colombia, and Mexico in the 1950s. He found that children more exposed to the eradication campaign earned higher incomes during adulthood, but the effect on years of education was inconsistent across countries. For the Swedish case, Lazuka (2018) found that the introduction of sulpha antibiotics to treat pneumonia during the 1930s created a health improvement for children exposed to the drug that would later translate into higher incomes (up to $5.1 \%$ higher) during late adulthood.

This paper contributes to the existing literature by exploring the economic effects of the introduction of a vaccine that provided immunity for an epidemic disease as was polio, employing a causal approach, and relying on high-quality Swedish register data. To the best of the authors' knowledge, no empirical studies have been conducted into the long-term individual effects of having immunity to this particular disease, whether in Sweden or in any other country. 


\section{Methodological Approach}

The identification strategy used in this paper is similar to that of Bleakley (2007). It rests on three characteristics of the introduction of the vaccine in Sweden. First, as stated in section 2, the development of the vaccine against polio was made possible due to critical research and innovations in the chemical and medical sciences that happened all over the world, sometimes simultaneously, and always built upon each other to further advance the possibilities of science. The fact that research into polio vaccination was being done in France, Sweden, and the United States at the same time, and that this research was in turn made possible by previous investigations made somewhere else in the world really supports the argument that this was an innovation that can be considered reasonably exogenous to the Swedish society, the aims of its governments, or the scope of its scientists.

Second, the introduction of the vaccine can be thought of as sudden, as well as exogenous. Given the epidemic aspect of the disease, upon the discovery of a safe and effective vaccine its use became widely available almost immediately in most of the developed world. In Sweden, the introduction of the vaccine in 1957 led to the eradication of wild poliovirus from the country in less than 10 years, which in historical terms can be considered a very short time.

Finally, given the transmission mechanism of polio, different areas of the country had different incidence rates of the disease (see Figure 2). People that inhabited regions with higher incidence rates of polio had, in principle, more to gain from the availability of the vaccine than those people living in areas where the disease had naturally low occurring rates. Figure 3 shows that, indeed, areas where polio infections where more abundant in the pre-vaccine years experienced a larger decline of incidence rates after the vaccine was introduced. Since there was virtually no variation in the timing of vaccine introduction across the country, it is this heterogeneity in the incidence rates of polio that allows for a treatment/control strategy, where our approach is basically comparing the effect that the introduction of the vaccine had on the outcomes of those exposed to it in counties with low and high incidence of the disease.

Consequently, the model estimated is as follows:

$$
Y_{i c t}=\beta_{0}+\beta_{1} H_{c}^{\text {pre }} \cdot \text { Post }_{t}+\delta_{c}+\delta_{t}+\gamma X_{i}+\varphi_{c t}+\epsilon_{i c t}
$$

Where $Y_{i c t}$ is any of the four outcomes of interest for individual $i$, born in county $c$, in year $t$. Fixed effects for both county and year of birth are captured through $\delta_{c}$ and $\delta_{t}$. $X_{i}$ is a vector of individual-level controls, $\varphi_{c t}$ is a set of county-specific linear trends, and $\epsilon_{i c t}$ is the error term. The main variable of interest, $H_{c}^{\text {pre }} \cdot$ Post $_{t}$, is constructed by two interacted variables, $H_{c}^{\text {pre }}$ denotes the prevalent incidence rate of polio in county $c$ at the time of the introduction of the vaccine, in our case it is computed as the average incidence rate of the period 1952-1956; while Post $_{t}$ is a dummy variable indicating whether or not the year of birth $t$ is equal or later than 1947. The coefficient of interest, $\beta_{1}$, is the differences-in-differences (DiD) estimate for the effect of the vaccine introduction on the outcome of interest, with the reference group being those living in areas with low polio incidence.

While our model, due to treatment definition, is not exactly a standard DiD model, it is a variation on the classic setting and therefore we need to check for standard assumptions to hold. A central assumption of the DiD model is that the outcomes for those in the control and the treatment 
Figure 3: Areas with High Polio Incidence saw a Greater Decline as Consequence of Vaccine Introduction.

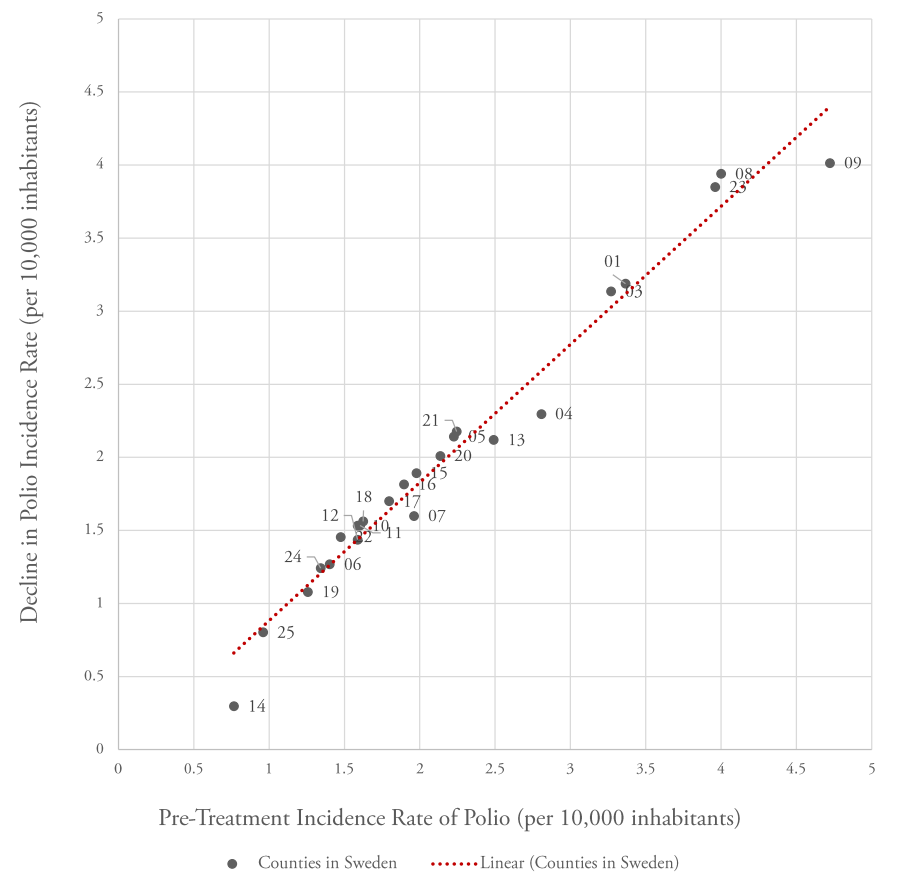

Note: Each dot in the graphs corresponds to one of Sweden's counties. The $x$ axis shows the pre-treatment incidence rates of polio in each of the counties of Sweden. The $y$ axis shows the county-level decline in polio incidence rates as a consequence of the vaccine, in absolute terms. Pre-treatment incidence rates are the 5-year average county-level incidence rate of polio (1952-1956) and the decline is calculated based on the post-treatment rates, which are defined as the 5-year average county-level incidence rate of polio (1957-1961). The codes for each data point correspond as follows: 01 Stockholm Län (including Stockholm Stad), 03 Uppsala Län, 04 Södermanlands Län, 05 Östergötlands Län, 06 Jönköpings Län, 07 Kronobergs Län, 08 Kalmar Län, 09 Gotlands Län, 10 Blekinge Län, 11 Kristianstads Län, 12 Malmöhus Län, 13 Hallands Län, 14 Göteborgs och Bohus Län, 15 Älvsborgs Län, 16 Skaraborgs Län, 17 Värmlands Län, 18 Örebro Län, 19 Västmanlands Län, 20 Kopparbergs Län, 21 Gävleborgs Län, 22 Västernorrlands Län, 23 Jämtlands Län, 24 Västerbottens Län, 25 Norrbottens Län.

Source: Author's calculations with data from Statistiska Centralbyrån.

groups behave in a similar way prior to the introduction of treatment (the so-called parallel trends assumption). In Appendix 2 the results from the graphic analysis of the outcomes is presented, which support the case that, for the outcomes and cohorts studied, it is reasonable to believe that the assumption holds true.

Finally, Bertrand et al. (2004) stress that, when estimating DiD models through Ordinary Least Squares regressions, the standard errors of the estimation might be inconsistent due to lack of, or incorrect, clustering. Empirical studies have often clustered at levels that resulted in a small number of clusters and an incorrect calculation of the standard errors, which has lead to an over-rejection of the null hypothesis in this type of analyses. To address this subject and avoid this particular pitfall, all the models estimated and presented in this paper have standard errors clustered in two dimensions: year and county of birth. This renders a relatively large number of clusters, while capturing some of the cohort and county variation not already explained in equation (1) by the fixed effects included (Cameron and Miller, 2015). 


\section{Data}

In this paper two types of data were used, one containing county-level information about poliomyelitis incidence and another containing individual-level socio-economic information. The county-level data on yearly new cases of poliq ${ }^{9}$ (akut barnförlamning), as well as the population-at-risk, was compiled from the yearly public health (Allmän Hälso- och Sjukvård) and population (Befolkningsstatistik) reports that Statistics Sweden (Statistiska Centralbyrån, 1911ab) has provided since 1911 in a consistent and comparable fashion.

Based on the data obtained from these sources, we were able to calculate the incidence rate of polio. The incidence rate shows how many cases occurred and were reported by doctors in each county of Sweden per 10,000 inhabitants. Population-at-risk is the county's total population on January 1 of each year ${ }^{10}$. The county-level incidence rate of polio forms the crucial part of the treatment identification strategy described in the next section, and the variable $H_{\text {pre }}$ is constructed based on it as the 5 -year average incidence rate per county in the years immediately before the introduction of the vaccine.

The individual-level data for this study was obtained from the Swedish Interdisciplinary Panel (SIP), a database hosted at the Centre for Economic Demography at Lund University, which provides register data for the entire Swedish population across the 20th century and, for the period 1968-2011, also provides detailed information on incomes, health, pensions, and other related economic outcomes. The cohorts included in this study are those born in Sweden between 1937 and 1966. Details of the variables included in the present study can be found on Table 1

For this paper, three different outcomes were constructed from the SIP data. The first of this is the natural logarithm of the average income between the ages of 35 and $45^{11}$ This measure was chosen because it fulfills two conditions, first, it measures income in a long-term perspective, given that treatment was given during childhood, and the 10-year average smooths sudden transitory fluctuations; secondly, it is a measure that is available for all but one of the cohorts in our sample, in other words, everyone included in our sample (except those born in 1967, which were excluded from the analysis) had turned 45 by 2011 , the last date available in the registers.

The second outcome, years of education, was calculated using the educational register and the method described in Antelius and Björklund (2000). They assessed the reliability of Swedish register data for explaining income disparities in the method pioneered by Mincer (1974). They suggest that the data on highest degree obtained found in the registers can be transformed into a measure of the average years of education associated with such degree, to account for length differences in levels below the highest degree attained. Although more accurate methods have been developed for the Swedish data, for example that of Fischer et al. (2016), they rely on census data for 1970, and most of our treated cohorts finished their education after that year. This would effectively change the

\footnotetext{
${ }^{9}$ Swedish doctors were legally obliged to report any case of dangerous epidemic diseases, and until 1967 polio was classified as one. A sample of the statistical reports used for this purpose can be found in the Appendix 1 .

${ }^{10}$ While we would have preferred to use only the population under 10 at the beginning of each year, the data available provides no such detail at the county level.

${ }^{11} \mathrm{By}$ income here, we mean yearly labor-related earnings. This definition includes salary and labor-related nonwage monetary earnings. In practice is very similar to wage income, but not for every case, which is why we took the broader definition. Furthermore, we chose this instead of total income to exclude capital gains, pensions, or inheritances for instance, since these are not related to labor productivity.
} 
Table 1: Summary Statistics

\begin{tabular}{|c|c|c|c|c|c|}
\hline \multicolumn{6}{|c|}{ Whole Sample } \\
\hline Variable & Mean & (Std. Dev.) & Min. & Max. & $\mathbf{N}$ \\
\hline Ln(Average Income 35-45) & 11.95 & $(0.73)$ & 0.167 & 17.329 & $2,132,769$ \\
\hline Years of Education & 11.38 & $(1.99)$ & 7 & 15.5 & $2,132,769$ \\
\hline № of Hospitalizations & 4.08 & $(6.59)$ & 1 & 529 & $1,430,424$ \\
\hline$H^{\text {pre }}$ & 2.11 & $(0.93)$ & 0.765 & 4.722 & $2,132,769$ \\
\hline Post & 0.84 & $(0.36)$ & 0 & 1 & $2,132,769$ \\
\hline Female & 0.49 & $(0.50)$ & 0 & 1 & $2,132,769$ \\
\hline Mother's age at Birth & 26.79 & $(5.43)$ & 13 & 50 & $2,132,769$ \\
\hline Mother's Education & 0.19 & $(0.39)$ & 0 & 1 & $2,132,769$ \\
\hline Father's Education & 0.20 & $(0.39)$ & 0 & 1 & $2,132,769$ \\
\hline Year of Birth & & & 1937 & 1966 & $2,132,769$ \\
\hline County of Birth & & & 1 & 25 & $2,132,769$ \\
\hline \multicolumn{6}{|c|}{ Men } \\
\hline Ln(Average Income 35-45) & 12.14 & $(0.67)$ & 0.167 & 17.329 & $1,090,835$ \\
\hline Years of Education & 11.16 & $(1.99)$ & 7 & 15.5 & $1,090,835$ \\
\hline № of Hospitalizations & 4.18 & $(7.29)$ & 1 & 529 & 629,521 \\
\hline$H^{\text {pre }}$ & 2.12 & $(0.93)$ & 0.765 & 4.722 & $1,090,835$ \\
\hline Post & 0.84 & $(0.36)$ & 0 & 1 & $1,090,835$ \\
\hline Mother's age at Birth & 26.81 & $(5.42)$ & 13 & 50 & $1,090,835$ \\
\hline Mother's Education & 0.19 & $(0.39)$ & 0 & 1 & $1,090,835$ \\
\hline Father's Education & 0.20 & $(0.39)$ & 0 & 1 & $1,090,835$ \\
\hline Year of Birth & & & 1937 & 1966 & $1,090,835$ \\
\hline County of Birth & & & 1 & 25 & $1,090,835$ \\
\hline \multicolumn{6}{|c|}{ Women } \\
\hline Ln(Average Income 35-45) & 11.75 & $(0.74)$ & 0.738 & 17.116 & $1,041,934$ \\
\hline Years of Education & 11.62 & $(1.97)$ & 7 & 15.5 & $1,041,934$ \\
\hline № of Hospitalizations & 4.01 & $(5.99)$ & 1 & 391 & 800,902 \\
\hline$H^{\text {pre }}$ & 2.12 & $(0.93)$ & 0.765 & 4.722 & $1,041,934$ \\
\hline Post & 0.84 & $(0.37)$ & 0 & 1 & $1,041,934$ \\
\hline Mother's age at Birth & 26.78 & $(5.43)$ & 13 & 50 & $1,041,934$ \\
\hline Mother's Education & 0.18 & $(0.39)$ & 0 & 1 & $1,041,934$ \\
\hline Father's Education & 0.19 & $(0.39)$ & 0 & 1 & $1,041,934$ \\
\hline Year of Birth & & & 1937 & 1966 & $1,041,934$ \\
\hline County of Birth & & & 1 & 25 & $1,041,934$ \\
\hline
\end{tabular}

Source: Author's calculations with data from Statistiska Centralbyrån. Data for Polio Incidence Rates come from yearly reports on population and health from 1911 until 1970. Individual Level data comes from the Swedish Interdisciplinary Panel, which contains register data for the period 1968-2011. Hospitalizations is measured as number of hospital admissions in adulthood. $H^{\text {pre }}$ is measured in cases per 10,000 inhabitants. The variables Post, Female, Mother's Education, and Father's Education are dummies, and the mean of these variables should be read as the percentage of ones in each variable (e.g. $0.49=49 \%)$.For a detailed description of the variable constructions see the main text of the data section.

direction of the coefficient, since mere age differences would make it appear as if the older cohorts had more years of education and the vaccine reduced them for the treated ones ${ }^{12}$

\footnotetext{
12 Fischer et al. (2016) developed a methodology, customized for the Swedish educational system during the 19301960 period, that is sensitive to the different configurations of basic education. Taking advantage that the 1970 census has a specific question on the length and type of education undertaken, the length of each individual's basic education can be calculated without making any assumptions as to how long it was. This data can be then complemented with the Education Register information on highest degree obtained by the individual. Therefore, people with only basic education will be accurately described by the census, while people with higher education will have their information complemented with the register. Because of the lack of uniformity in the length of basic education across Sweden, as well as the reforms on compulsory education length (1936-1949), this method more accurately describes the real years of education than estimation using only the register data on highest degrees. However, this
} 
The third outcome is our selected measure of long-term health. It counts the number of times any given individual was admitted to the hospital, as stated in the inpatient register. We chose to focus on the number of admissions, rather than the number of days in hospital, to be able to distinguish those who, throughout their lives, required constantly medical attention, from those who might have had one illness or accident that required them to spend several days admitted 13 .

The models specified in the next section all include the same controls; these are individual characteristics that are thought to have an effect on the outcomes through their own channels, and must therefore be included as a control-strategy. The variable female is a dummy variable that takes the value of 1 if the individual is a woman, and zero otherwise. Of our working sample, around $49 \%$ are women.

The information on parental educational achievement was obtained from the 1970 census. Although in an ideal scenario we would like to observe parental education at child's birth, and not some years later, the hypothesis here is that this time delay caused by data availability shouldn't be a considerable issue because, for the most part, parents tended to start having children after they had completed their education, or at least that is a plausible scenario in the period 1930-1960 which we are studying. If this is the case, measuring the education of a parent, for instance, at age 28 and 68 should not yield different results. Based on the data from the census, we created two dummy variables (one for the mother and another one for the father) that took the value of 1 if the parent in question had more than elementary education and 0 if he or she had completed only the compulsory education 14 These two variables should control for income differences that arise from having a parent with above average education.

Previous studies have found a relationship between being born to a young mother and certain disadvantages later in life. For instance, Levine et al. (2001) found that children born to young mothers were more prone to behavioral problems in the teenage years, while Pogarsky et al. (2006) found that these individuals were at higher risks of drug use, gang membership, unemployment, and early parenthood. Studies have also found an impact on educational attainment (and therefore, adult income), both López Turley (2003) and Levine et al. (2001) find that the "young mother penalty" on test scores and attainment can be almost completely explained by the maternal family characteristics. Since our data sources offer little detail on parental characteristics, we decided to include a variable to indirectly control for this. The variable Mother's Age at Birth measures the age of an individual's mother when she gave birth to them. We also include its quadratic form to control for possible non-linearities in the effect of mother's age.

Since it's expected that the outcomes will vary across individuals based on time and geography, we control for the individual's year and county of birth. In this way, common shocks that are shared across cohorts, or conditions specific to certain county should be controlled by the fixed effects. The cohorts included in the sample are those born in Sweden between 1937 and 1966, while the codes

\footnotetext{
question does not appear in any later census, reason why we opted out of using this method

${ }^{13}$ In a secondary analysis we attempted to use only those hospitalizations that could be traced directly to a consequence of polio, what is known as post-polio syndrome (PPS). However the number of cases reported under this diagnosis was too small (70 in our sample of around 2 million) for any results to be calculated.

${ }^{14}$ For the cohorts of parents, finishing compulsory education was the mean, so this variables capture the effect of having a parent who has more education than average.
} 
(1-25) of the historical counties of Sweden are those found in Statistiska Centralbyrån (1911a b).

Finally, an indicator for treatment Post $t_{t}$ is generated. This is a variable that takes the value of 1 if the individual was born in or after 1947, and denotes whether or not he or she was exposed to the polio vaccine before the age of 10 . As previously noted, the population most at risk of contracting the disease are those under 5 years old, where the chances are highest, however, we include those up until age 10 for the historical reasons described earlier, and to control for the fact that the risk of contracting the disease has a negative slope, and decreases, but not disappears after age 5 .

\section{Results}

In this section, the results from the estimations of the models specified previously are discussed. Table 2 presents the results for the regressions on the effect of exposure to the vaccine against polio on adult income, educational attainment, and hospitalizations, according to equation 1 Three models were fitted for every outcome, the first one containing only the basic specification with the treatment variable and county-of-birth and year-of-birth fixed effects; the second one adds a vector of controls, that include the individual's gender, years of education (except when this is the outcome), linear and squared age of the mother at the individual's birth, and parental educational achievement; the last column shows models that include also the interactions of the vector of controls with $H^{p r e}$, the average pre-treatment incidence rate, to control for the potential differences in characteristics based on the incidence of the disease. All models shown control for county-specific linear trends.

In the first panel of Table 2 we can appreciate a small, negative effect of exposure to the vaccine on the logarithm of average income between ages 35-45. Our initial hypothesis, based on previous evidence from other diseases and treatments, was that the vaccine would impact more positively the income of those individuals who were born in counties where the disease was more prevalent, since they had more to gain from eradication. The results from our estimations show that was not the case for polio. The negative effect, however statistically significant, is considered way too small (under $1 \%$ of a 10-year average income ${ }^{15}$ to have any economic relevance. Our interpretation is that this might reflect very slight differences in adult earnings that coincide with the polio epidemics, but that were uncorrected, or failed to disappear, when the disease was eradicated ${ }^{16}$. An alternate explanation might relate to differences in behavior between people who suffered severe infections and those who recovered, for instance Gensowski et al. (2018) suggest that paralytic polio survivors engage in a sort of compensatory behavior throughout their lives, altering their educational and occupational choices to fit their skills better (by, for instance, avoiding unskilled, physical work in favor of more white-collar or non-manual professions). However, we find no evidence that this sort of behavior was present for the Swedish case (See Appendix 16).

The second panel of Table 2 shows that there was no statistically significant differences in educational achievements among those exposed to the vaccine against polio in high and low incidence

\footnotetext{
${ }^{15}$ To put this number into perspective, consider Bleakley (2007) where eradication of hookworm disease also eliminated the estimated $40 \%$ income decrease that was a consequence of suffering the infection. By comparison, individuals in our sample lost (depending on pre-treatment incidence rates) somewhere between $0.6 \%$ and $1.8 \%$ of their average yearly adult income

${ }^{16}$ The interpretation that this effect is not related to the vaccine itself is supported by two placebo tests presented in Appendices 14 and 15 In these tests, we redefine treatment to different dates and still find the very small effect on income, which suggest they are not dependent on the 1957 introduction of the polio vaccine, but on some incomerelated trends that coincide temporally with the vaccine.
} 
Table 2: The Effect of Polio Vaccination on Income, Educational Achievement, and Hospitalizations

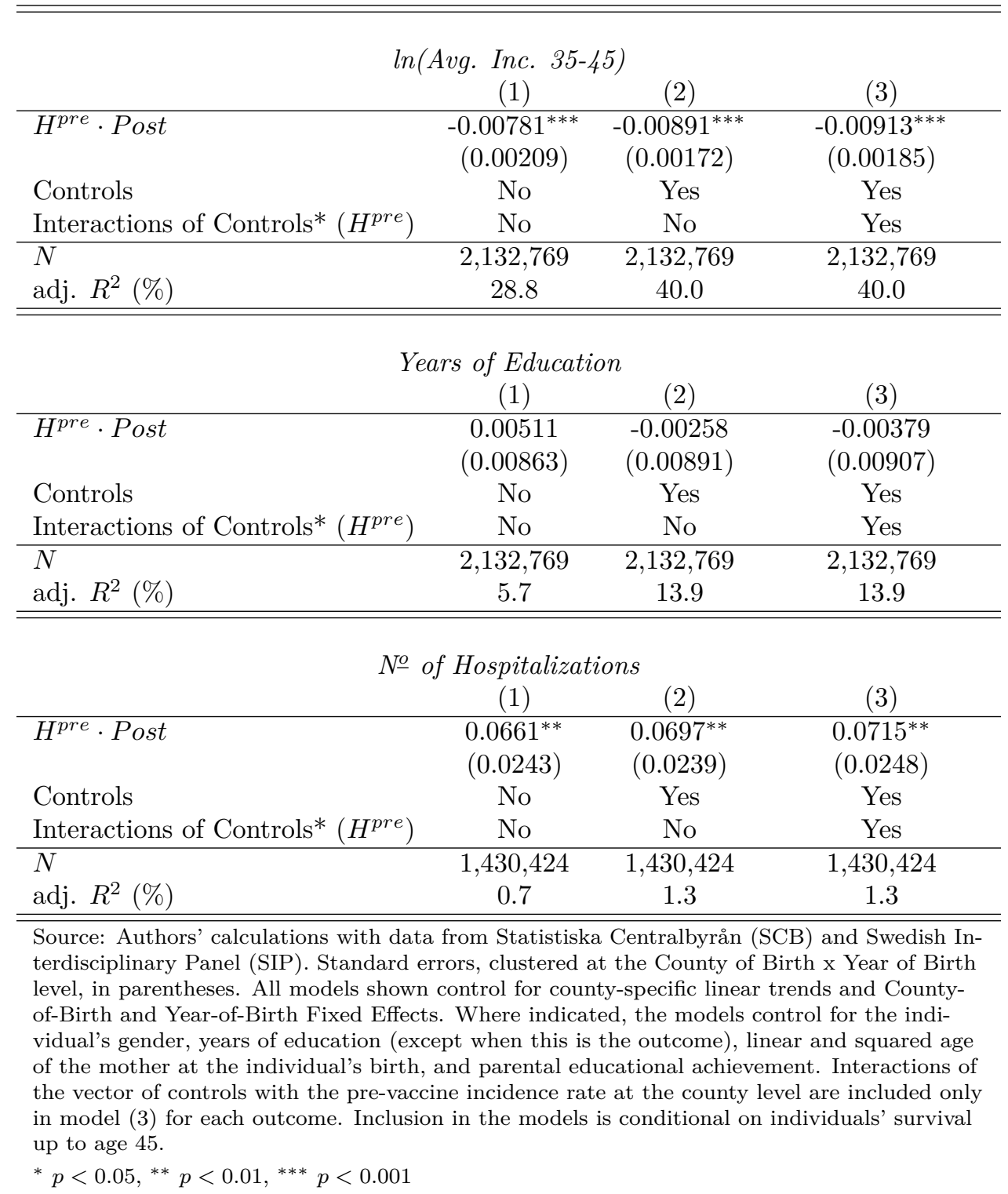

areas of the county. Similarly, the third panel shows that the expected decrease in the number of hospitalizations appears not to exists. In this case, as was for income, the effect has the opposite sign from our initial expectation, but while the coefficients have statistical significance, their magnitude is so small (0.06-0.07 hospitalizations, from a mean of 4.085, or 0.009 standard deviations) that they retain little to none economic significance.

Table 3 presents the results for the by-gender estimations of the vaccine's effect on our three selected outcomes. The reason for this stratified analysis is that it is reasonable to hypothesize that the effect of exposure to the vaccine might be completely different between the genders due to education, fertility, or labor-market related behaviors(e.g. occupational choices or selection into less physically demanding jobs). Our analysis shows, however, only small differences, and they don't drastically change the results or the interpretation we obtained from Table 2. For the case of average income, it shows that the negative effect is smaller in magnitude for men than for women, with the boys 
Table 3: The Effect of Polio Vaccination on Income, Educational Achievement, and Hospitalizations, by gender

$$
\ln (\text { Avg. Inc. 35-45) }
$$

\begin{tabular}{l} 
Men $(N=1,090,835)$ \\
\hline$H^{\text {pre }} \cdot$ Post \\
Controls \\
Interactions of Controls $\times\left(H^{\text {pre }}\right)$ \\
\hline adj. $R^{2}(\%)$ \\
\hline Women $(N=1,041,934)$ \\
\hline$H^{\text {pre }} \cdot$ Post \\
Controls \\
Interactions of Controls $\times\left(H^{\text {pre }}\right)$ \\
\hline adj. $R^{2}(\%)$ \\
\hline \hline
\end{tabular}

$\begin{array}{ccc}-0.00542^{*} & -0.00611^{* * *} & -0.00734^{* *} \\ (0.00213) & (0.00184) & (0.00203) \\ \text { No } & \text { Yes } & \text { Yes } \\ \text { No } & \text { No } & \text { Yes } \\ 25.5 & 31.6 & 31.6\end{array}$

\section{Years of Education}

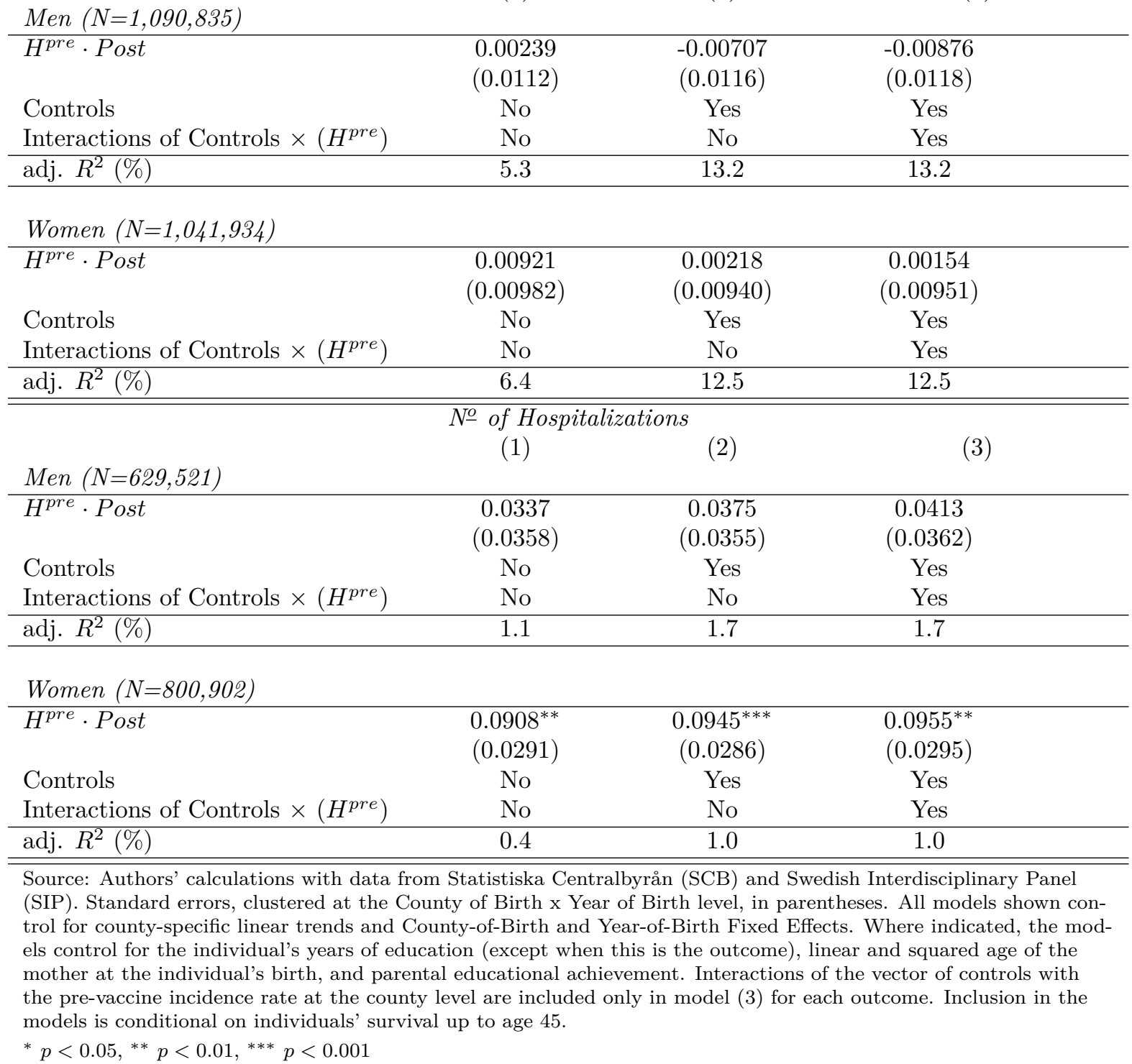


exposed to the vaccine in high-polio areas earning $0.7 \%$ less in average than their low-polio counterparts (this equals roughly a $1 \%$ of a standard deviation) and the equivalent effect for women being about just $1 \%$ ( $1.5 \%$ of a standard deviation). Again, our main take away from these models is that the vaccine appears to not benefit more those exposed to it in areas where polio was more prevalent, contrary to the initial expectation. In the second panel of Table 3 it is clear that there were no visible effects of exposure to the vaccine on the total years of education achieved by either men or women. Finally, in the last panel, we can observe that the small, positive effect on hospitalizations is present in a statistically significant manner only for women. Once more, the magnitude of the effect (0.09 more hospitalizations over adulthood, or $1.5 \%$ of a standard deviation) is probably too small to be considered economically significant. These small differences between men and women in the models are, however, not statistically significant from each other ${ }^{17}$, and little can be said about gender differences in the effect of the vaccine. The results from our main model are not sensitive to different specifications of our treatment variable (see Appendices 3, 4, 7,13 and 14, different definitions of income (see Appendix 12 or hospitalizations (see Appendix 7), nor to the inclusion or exclusion of certain specific birth cohorts (see Appendices 8, 9, 10, and 11) or counties of birth (see Appendix 5 [18.

Why was the expected effect of exposure to the vaccine so different from the results presented in this section? The answer to that might have something to do with the theoretical assumptions on which our hypothesis was constructed upon. There is extensive literature that shows that harsh conditions in early life have a lasting effect that can be felt even on later-life outcomes (Barker, 1990. Bengtsson and Lindström, 2000, Case and Paxson, 2009, Myrskylä et al., 2013; Quaranta, 2013). It follows logically, and so has some research found, that removing an obstacle, a harshness, or a disease from early life can have the opposite impact, benefiting individuals who experience this improved environment and having also lasting repercussions in later-life (Bleakley, 2007, 2010, Lazuka, 2018). We embarked on this study assuming that, as a highly infectious disease, poliomyelitis should behave like other diseases studied, scarring individuals who were exposed to epidemics, regardless of whether or not they contracted the disease or suffered mild or severe symptoms from it. Following that line of thought, eradicating polio, via vaccination, should have created a disease-free environment that benefited everyone, increasingly so those in areas of the country where the disease was more prevalent. The results however, show that the vaccine had no such impact.

The logical question to follow is to ask whether our premise was, for some reason flawed. Did polio really scar people, as whooping cough or influenza did in the past? In this section we address this question and, in doing so, we hope to put the results from the previous section more in their proper context.

Scarring effects are often studied by analyzing a deviation from the trend in a measure, usually infant mortality rates (IMR), that can be related to an outbreak of a disease. For example, the 1918 outbreak of influenza (also known as the Spanish Flu) has been used to study the long term effects

\footnotetext{
${ }^{17}$ We performed a Z-test $\left(Z=\frac{\delta \beta}{\sqrt{S E \beta_{1}^{2}+S E \beta_{2}^{2}}}\right)$ on the coefficients being different from each other, and none rejected the null hypothesis that the difference between coefficients was equal to zero.

${ }^{18}$ The model specification (DiD) is, however, vital since it allows us to correctly identify the effect of interest. In Appendix 6 we conducted a basic pre-post analysis (being born before/after the vaccine as the main explanatory variable), ignoring the spatial variation in incidence rates. The results, as expected, are quite different and are capturing the exclusion of $H^{\text {pre }}$ and the year of birth fixed effects. Disentangling the effect of the vaccine from that of the birth cohorts requires the use of our original specification.
} 
of exposure to this disease on outcomes such as adult mortality (Myrskylä et al. 2013) and adult educational and income achievements (Almond, 2006), while outbreaks of measles, scarlet fever, and whooping cough have also shown to have long term impact on female economic attainment and reproductive health (Quaranta, 2013).

In our case, we will test the scarring hypothesis of polio by analyzing the last ever outbreak of the disease in Sweden, occurring during 1953. Since polio-related mortality is considered quite low, we will analyze changes in the incidence rate of the disease, which reflects how many cases were reported per 10,000 inhabitants of every county. A quick look back at Figure 1 will remind the reader that there were several outbreaks of polio since the beginning of the 20th century, with the biggest peaks happening in 1911 and 1953.

In an ideal scenario, we would like to have a very low incidence rate both before and after a big, sudden epidemic in order to compare also children from ages 0 to 10, as in the main analysis. However the recurrent nature of polio outbreaks means that using more than two or three birth cohorts at a time would include children who were exposed to multiple outbreaks in the unexposed category, reason why we opted for a cleaner design. The two biggest outbreaks of polio provide us with this settings, but since we have no data going as far back as 1911, we shall focus on the 1953 outbreak, comparing the outcomes of those born before (ages $1 \& 2$ ) or during (age 0 ) the outbreak, with those who were born after it (also ages 0-2), avoiding the exposure to the disease load. Focusing only on those aged 0-2, we are able to have a clear setting, since relatively very low rates of polio occurred both before and after the 1953 pandemic. Including more cohorts would not be optimal, since 19491950 saw somewhat high rates. If there are any scarring effects of polio, individuals born before or during the largest epidemic should show some reduction in adult income and years of education, or an increase in the number of hospitalizations.

Table 4: Scarring Effects of Polio Exposure during Early Life, by year of exposure to the 1953 Polio Outbreak

\begin{tabular}{|c|c|c|c|}
\hline & $\begin{array}{ll} & (1) \\
\ln (\text { Avg. } & \text { Inc. } 35-45)\end{array}$ & $\begin{array}{c}(2) \\
\text { Years of Education }\end{array}$ & $\begin{array}{c}(3) \\
\text { No of Hospitalizations }\end{array}$ \\
\hline $\begin{array}{l}\text { Third Year of Life } \\
\text { (Age 2) }\end{array}$ & $\begin{array}{c}0.0000733 \\
(0.0000641)\end{array}$ & $\begin{array}{c}0.000372 \\
(0.000648)\end{array}$ & $\begin{array}{c}-0.00103 \\
(0.000832)\end{array}$ \\
\hline $\begin{array}{l}\text { Second Year of Life } \\
\text { (Age 1) }\end{array}$ & $\begin{array}{c}0.000115 \\
(0.0000648)\end{array}$ & $\begin{array}{c}0.000524 \\
(0.000374)\end{array}$ & $\begin{array}{c}0.000177 \\
(0.000977)\end{array}$ \\
\hline $\begin{array}{l}\text { Year of Birth } \\
(\text { Age } 0)\end{array}$ & $\begin{array}{c}0.0000756 \\
(0.0000645)\end{array}$ & $\begin{array}{l}0.000749^{*} \\
(0.000290)\end{array}$ & $\begin{array}{l}-0.000500 \\
(0.000673)\end{array}$ \\
\hline $\begin{array}{l}N \\
\text { adj. } R^{2}(\%)\end{array}$ & $\begin{array}{c}508,297 \\
11.4\end{array}$ & $\begin{array}{c}508,297 \\
10.2 \\
\end{array}$ & $\begin{array}{c}320,366 \\
0.3\end{array}$ \\
\hline \multicolumn{4}{|c|}{$\begin{array}{l}\text { Source: Authors' calculations with data from Statistiska Centralbyrån (SCB) and Swedish In- } \\
\text { terdisciplinary Panel (SIP). Standard errors, clustered at the County of Birth x Year of Birth } \\
\text { level, in parentheses. All models shown control for County-of-Birth and Year-of-Birth Fixed } \\
\text { Effects, the individual's years of education (except when this is the outcome), linear and } \\
\text { squared age of the mother at the individual's birth, and parental educational achievement. } \\
\text { Inclusion in the models is conditional on being born between } 1951 \text { and } 1956 \text { and survival up } \\
\text { to age } 45 \text {. } \\
{ }^{*} p<0.05,{ }^{* *} p<0.01,{ }^{* * *} p<0.001\end{array}$} \\
\hline
\end{tabular}

Table 4 shows the results of our models on the scarring effects of polio. In each model, besides the 
usual controls and fixed effects, we include a variable that takes the value of 0 if the individual was born after the 1953 epidemic, and takes the value of the 1953 incidence rate of polio in the county of birth otherwise; we also allow for the scarring effect to show for different age-at-exposures, from 0 to 2 years of age. The coefficient of interest in this case shows the effect of exposure to the 1953 polio epidemic, by age of exposure. For example, in the case of education, it shows the difference in educational achievement (in years) between those exposed to the epidemic and those who were not. The results show no statistically significant differences in outcomes between those exposed to a high load of polio on the first years of life and those who were not.

Table 5: Scarring Effects of Polio Exposure. Comparison of cohorts born immediately before and after the 1953 Polio Outbreak

\begin{tabular}{lccc}
\hline \hline & $(1)$ & $(2)$ & $(3)$ \\
& $\ln ($ Avg. Inc. 35-45) & Years of Education & No of Hospitalizations \\
\hline Scarring effect & -0.0000403 & -0.0000455 & 0.00144 \\
& $(0.0000713)$ & $(0.000230)$ & $(0.00109)$ \\
\hline$N$ & 166,715 & 166,715 & 104,690 \\
adj. $R^{2}(\%)$ & 11.0 & 10.1 & 0.2 \\
\hline \hline
\end{tabular}

Source: Authors' calculations with data from Statistiska Centralbyrån (SCB) and Swedish Interdisciplinary Panel (SIP). Standard errors, clustered at the County of Birth x Year of Birth level, in parentheses. All models shown control for County-of-Birth and Year-of-Birth Fixed Effects, the individual's years of education (except when this is the outcome), linear and squared age of the mother at the individual's birth, and parental educational achievement. Inclusion in the models is conditional on being born in either 1952 or 1954 and survival up to age 45 .

${ }^{*} p<0.05,{ }^{* *} p<0.01,{ }^{* * *} p<0.001$

Furthermore, in Table 5 we narrow our analysis to include only those individuals born immediately before and after the 1953 epidemic (cohorts born in 1952 and 1954). This more focused analysis, however, yields the same results, with no significant differences in outcomes being observable between the exposed (1952) and "control" (1954) groups.

\section{Conclusion}

It appears that, unlike influenza, measles, or whooping cough, exposure to an epidemic of poliomyelitis does not affect everyone regardless of actual infection. It seems that the only affected long-term by the disease were those who ended up suffering the hardest symptoms of it. This result resounds specially clear when considering the detailed pathological aspects of the infection discussed in Section 2. Medical literature refers to polio as a disease that is extremely virulent, and infects virtually all the individuals from a population-at-risk, but it also singles out the disease as one that, unlike the most others, can cause both inapparent and apparent infections (Paul, 1971). The most recognizable symptoms associated with polio are only the most extreme ones resulting from apparent infections, while over $99 \%$ of those infected by the virus show and suffer only mild to no symptoms (inapparent infections).

In light of this, our results suggest that being exposed to a polio epidemic, but avoiding the paralytic symptoms derived from an advanced infection, does not leave any long term repercussions in adult income, educational achievement, or health. In other words, people who suffered inapparent 
infections of polio were known to make a full recovery medically speaking, but now it can also be said that they recover economically, and that their later-life outcomes do not seem to be affected by the disease. This being the case, the results from our main analysis in Section 6 seem more in accordance to logic. If there are no scarring effects from exposure to high loads of the disease in infancy (regardless of actual infection), then there should be no differential effect of the vaccine according to incidence rates of the disease.

Noteworthy is the fact that our results do not claim at all that the vaccine had no positive impacts for those vaccinated. The immediate health benefits of avoiding lifelong paralysis or disability are indisputable and self-evident. Our results speak, specifically, of a lack of long-term impact of exposure to the vaccine on adult outcomes, not because of personal characteristics or vaccine ineffectiveness, but because the disease appeared to be non-scarring, which in itself poses interesting questions for further research into the at-large scarring nature of diseases and epidemics.

\section{References}

Almond, D. (2006). Is the 1918 influenza pandemic over? Long-term effects of in utero influenza exposure in the post-1940 US population. Journal of political Economy, 114(4):672-712.

Almond, D. and Currie, J. (2011). Killing me softly: The fetal origins hypothesis. Journal of economic perspectives, 25(3):153-72.

Almond, D., Currie, J., and Duque, V. (2018). Childhood Circumstances and Adult Outcomes: Act II. Journal of Economic Literature, 56(4):1360-1446.

Antelius, J. and Björklund, A. (2000). How reliable are register data for studies of the return on schooling? An examination of Swedish data. Scandinavian Journal of Educational Research, $44(4): 341-355$.

Axelsson, P. (2004). Höstens spöke: de svenska polioepidemiernas historia. PhD thesis.

Axelsson, P. (2009). 'No os comáis esas manzanas! han estado en el suelo!': la epidemia de polio y las medidas preventivas en Suecia, desde la década de 1880 hasta la década de 1940. Asclepio, 61(1):23-38.

Barker, D. J. P. (1990). Fetal and infant origins of adult disease. British Medical Journal.

Becker, G. S. (1964). Human capital: A theoretical and empirical analysis, with special preferences to education. National bureau of economic research.

Bengtsson, T. and Broström, G. (2009). Do conditions in early life affect old-age mortality directly and indirectly? Evidence form 19th-century rural Sweden. Social Science and Medicine, 68(9 Online 13 March 2009):1583-1590.

Bengtsson, T. and Dribe, M. (2011). The late emergence of socioeconomic mortality differentials: A micro-level study of adult mortality in southern Sweden 1815-1968. Explorations in Economic History, 48:389-400.

Bengtsson, T. and Lindström, M. (2000). Childhood misery and disease in later life: The effects on mortality in old age of hazards experienced in early life, southern Sweden, 1760-1894. Population Studies, 54(3):263-277. 
Bengtsson, T. and Lindström, M. (2003). Airborne infectious diseases during infancy and mortality in later life in southern Sweden, 1766-1894. International Journal of Epidemiology, 32(2):286-294.

Bertrand, M., Duflo, E., and Mullainathan, S. (2004). How Much Should We Trust Differences-InDifferences Estimates?*. The Quarterly Journal of Economics, 119(1):249.

Bhalotra, S. R., Karlsson, M., Nilsson, T., and Schwarz, N. (2016). Infant Health, Cognitive Performance and Earnings: Evidence from Inception of the Welfare State in Sweden. IZA Discussion Papers No. 10339.

Bleakley, H. (2007). Disease and Development: Evidence from Hookworm Eradication in the American South*. The Quarterly Journal of Economics, 122(1):73-117.

Bleakley, H. (2010). Malaria eradication in the Americas: A retrospective analysis of childhood exposure. American Economic Journal: Applied Economics, 2(2):1-45.

Bundervoet, T. and Fransen, S. (2018). The educational impact of shocks in utero: Evidence from Rwanda. Economics \&3 Human Biology, 29:88-101.

Cameron, A. C. and Miller, D. L. (2015). A practitioner's guide to cluster-robust inference. Journal of Human Resources, 50(2):317-372.

Case, A. and Paxson, C. (2009). Early life health and cognitive function in old age. The American economic review, 99(2):104.

Chay, K. Y., Guryan, J., and Mazumder, B. (2009). Birth Cohort and the Black-White Achievement Gap: The Roles of Access and Health Soon After Birth. Technical Report 15078.

Cunha, F., Heckman, J. J., and Schennach, S. M. (2010). Estimating the technology of cognitive and noncognitive skill formation. Econometrica, 78(3):883-931.

Fagraeus, A. and Böttiger, M. (1980). Polio Vaccination in Sweden. Reviews of Infectious Diseases, $2(2): 274-276$.

Fischer, M., Karlsson, M., Nilsson, T., and Schwarz, N. (2016). The Sooner the Better? Compulsory Schooling Reforms in Sweden. IZA Discussion Papers No. 10430.

Fogel, R. W. and Costa, D. L. (1997). A theory of technophysio evolution, with some implications for forecasting population, health care costs, and pension costs. Demography, 34(1):49-66.

Gensowski, M., Nielsen, T. H., Nielsen, N. M., Rossin-Slater, M., and Wüst, M. (2018). Childhood Health Shocks, Comparative Advantage, and Long-Term Outcomes: Evidence from the Last Danish Polio Epidemic. Technical Report 24753.

Godlee, F. (2007). Milestones on the long road to knowledge. BMJ, 334(suppl 1):s2-s3.

Gothefors, L. (2008). The impact of vaccines in low-and high-income countries. Annales Nestlé (English ed.), 66(2):55-69.

Grossman, M. (1972). On the concept of health capital and the demand for health. Journal of Political economy, 80(2):223-255.

Helgertz, J. and Önnerfors, M. (2019). Public water and sewerage investments and the urban mortality decline in Sweden 1875-1930. The History of the Family (Forthcoming). 
Karimi, S. M. and Basu, A. (2018). The effect of prenatal exposure to Ramadan on children's height. Economics \& Human Biology, 30:69-83.

Lazuka, V. (2018). Infant health and later-life labour market outcomes: Evidence from the introduction of sulfa antibiotics in Sweden. Journal of Human Resources, 0817-9016R.

Levine, J. A., Pollack, H., and Comfort, M. E. (2001). Academic and Behavioral Outcomes Among the Children of Young Mothers. Journal of Marriage and Family, 63(2):355-369.

López Turley, R. N. (2003). Are Children of Young Mothers Disadvantaged Because of Their Mother's Age or Family Background? Child Development, 74(2):465-474.

Mincer, J. (1974). Schooling, Experience, and Earnings. National Bureau of Economic Research, Massachusetts, USA.

Myrskylä, M., Mehta, N. K., and Chang, V. W. (2013). Early life exposure to the 1918 influenza pandemic and old-age mortality by cause of death. American journal of public health, 103(7):e83e90.

Nathanson, N. and Martin, J. R. (1979). The epidemiology of poliomyelitis: enigmas surrounding its appearance, epidemicity, and disappearance. American Journal of Epidemiology, 110(6):672-692.

Paul, J. R. (1971). A History of Poliomyelitis. Yale University Press, New Haven, CT.

Pogarsky, G., Thornberry, T. P., and Lizotte, A. J. (2006). Developmental Outcomes for Children of Young Mothers. Journal of Marriage and Family, 68(2):332-344.

Quaranta, L. (2013). Scarred for Life. How conditions in early life affect socioeconomic status, reproduction and mortality in Southern Sweden, 1813-1968. PhD thesis.

Smallman-Raynor, M. and Cliff, A. (2006). A world geography. Poliomyelitis. Emergence to eradication. New York: Oxford University Press.

Statistiska Centralbyrån (1911a). Allmän Hälso- och Sjukvård. Statistiska Centralbyrån, P.A. Norstedt \& Söner., Stockholm, Sweden. (Yearly Volumes 1911-1979).

Statistiska Centralbyrån (1911b). Befolkningsstatistik. Statistiska Centralbyrån, P.A. Norstedt \& Söner., Stockholm, Sweden. (Yearly Volumes 1911-1979).

Wesslén, T., Lycke, E., Gard, S., and Olin, G. (1957). Inactivation of poliomyelitis virus by formaldehyde. Archives of Virology, 7(2):125-135.

World-Health-Organization (2017). Poliomyelitis Fact Sheet.

World-Health-Organization and others (2017). Polio vaccines: WHO position paper, March 2016-recommendations. Vaccine, 35(9):1197-1199.

Zinkernagel, R. M. (2001). Maternal antibodies, childhood infections, and autoimmune diseases. New England Journal of Medicine, 345(18):1331-1335. 


\section{Appendices}

Appendix 1: Statistical Report of Epidemic Diseases in Sweden. Abstract from 1912's Allmän Hälso- och Sjukvård (Statistiska Centralbyrån, 1911a)

TAB. 8 (Forts.). ÖVERSIKT ÖVER SJUKDOMSFALL I INFEKTIONSSJUKDOMAR ETC. 111

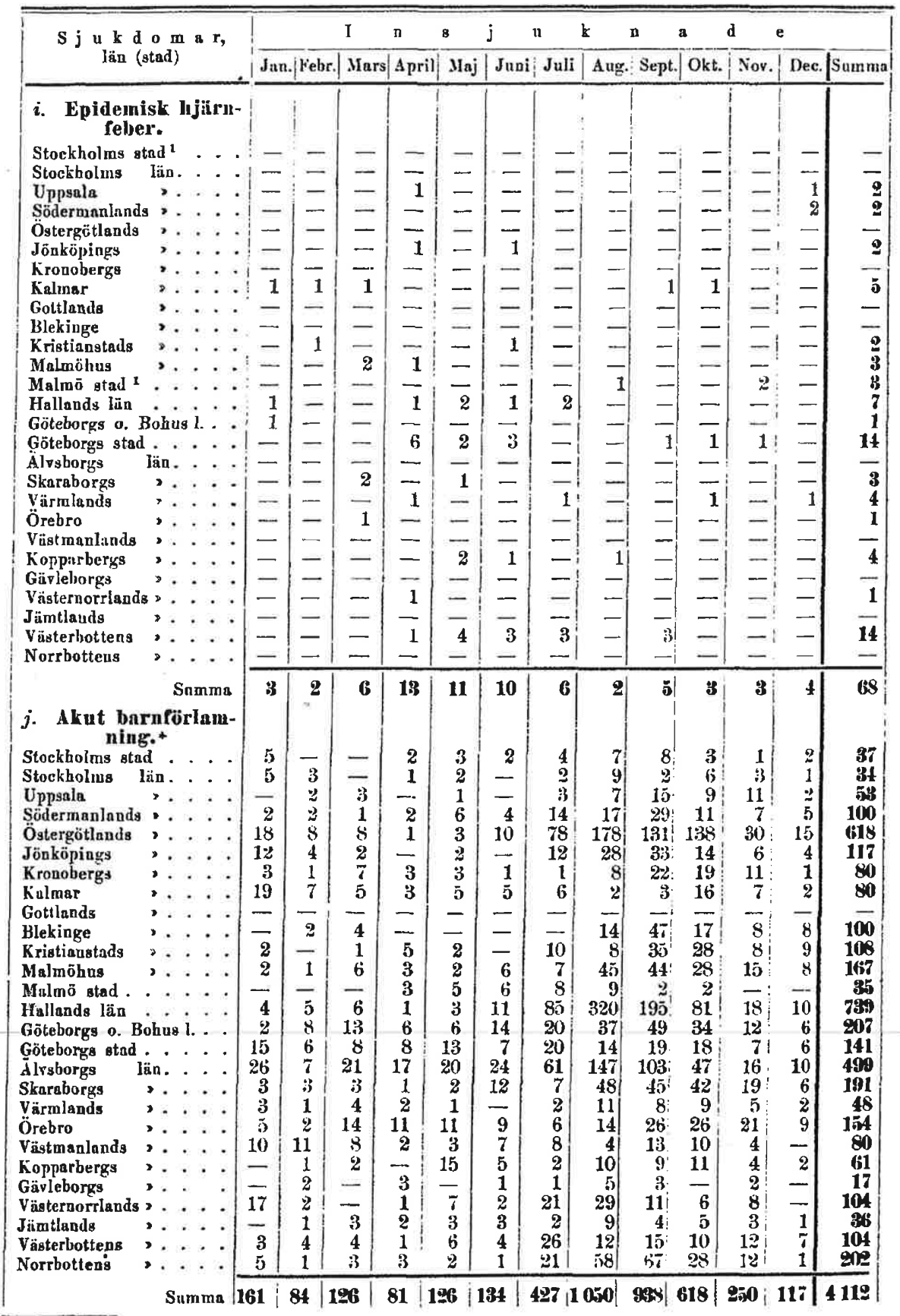

a Fnligt nppgifter från distriktaläkarne; avae endast fattiga sjuka. 
Appendix 2: Trends in later-life outcomes for cohorts born before and after the introduction of Polio Vaccine in Sweden by quartiles of pre-vaccination incidence rate $\left(H^{\text {pre }}\right)$

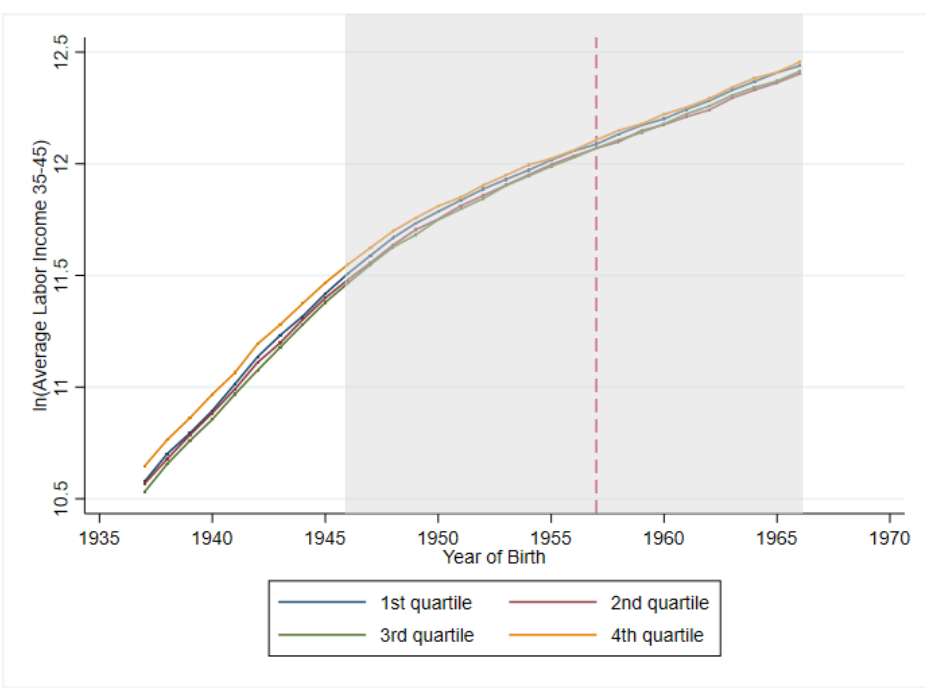

(a) Trend in $\ln$ (Average Income at ages $35-45)$

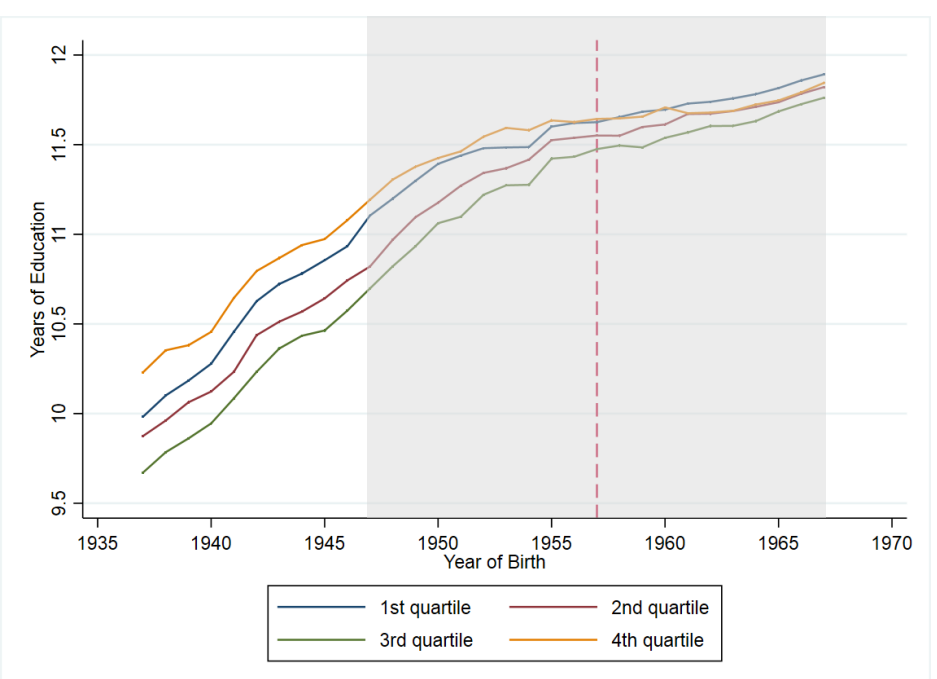

(b) Trend in Years of Education

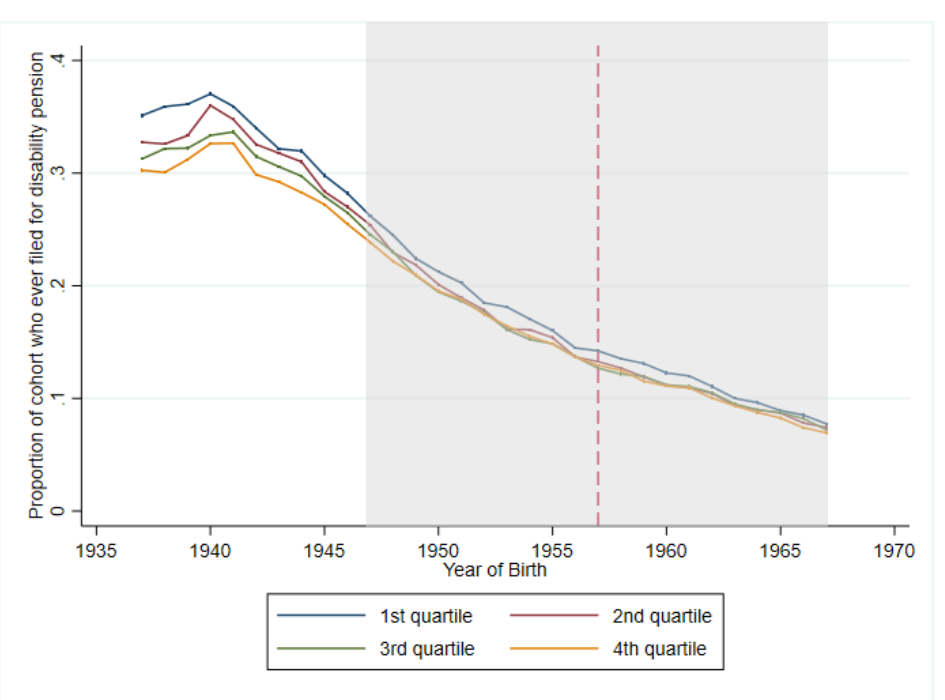

(c) Trend in Disability Pension

Note: The above graphs show the mean for the specified outcome by year of birth and region of birth (divided into quartiles, according to the baseline prevalence of Polio infections). The reference line marks 1957, the year when the vaccine was introduced in Sweden, and the shaded area marks the period 1947-1966, which includes the cohorts defined as exposed to the vaccine in childhood in the main models.

Source: Author's calculations with data from Statistiska Centralbyrån 
Appendix 3: Robustness Check: Main Model with $H^{\text {pre }}$ redefined as a 10-year average (1947-1956) of Polio Incidence Rate

\begin{tabular}{lccc}
\hline \hline & $\ln ($ Avg. Inc. 35-45) & \\
& $(1)$ & $(2)$ & $(3)$ \\
\hline$H^{\text {pre }} \cdot$ Post & $-0.00731^{*}$ & $-0.00733^{* *}$ & $-0.00747^{* *}$ \\
& $(0.00288)$ & $(0.00245)$ & $(0.00258)$ \\
Controls & No & Yes & Yes \\
Interactions of Controls* $\left(H^{\text {pre }}\right)$ & No & No & Yes \\
\hline$N$ & $2,132,769$ & $2,132,769$ & $2,132,769$ \\
adj. $R^{2}(\%)$ & 28.8 & 40.0 & 40.0 \\
\hline \hline
\end{tabular}

Years of Education

\begin{tabular}{lccc} 
& $(1)$ & $(2)$ & $(3)$ \\
\hline$H^{\text {pre }} \cdot$ Post & -0.00946 & -0.0154 & -0.0170 \\
& $(0.0121)$ & $(0.0118)$ & $(0.0120)$ \\
Controls & No & Yes & Yes \\
Interactions of Controls* $\left(H^{\text {pre }}\right)$ & No & No & Yes \\
\hline$N$ & $2,132,769$ & $2,132,769$ & $2,132,769$ \\
adj. $R^{2}(\%)$ & 5.7 & 13.9 & 13.9 \\
\hline \hline
\end{tabular}

№ of Hospitalizations

(1) $\quad(2)$

\begin{tabular}{lccc} 
& $(1)$ & $(2)$ & $(3)$ \\
\hline$H^{\text {pre }} \cdot$ Post & 0.0563 & 0.0576 & 0.0590 \\
& $(0.0330)$ & $(0.0326)$ & $(0.0334)$ \\
Controls & No & Yes & Yes \\
Interactions of Controls* $\left(H^{\text {pre }}\right)$ & No & No & Yes \\
\hline$N$ & $1,430,424$ & $1,430,424$ & $1,430,424$ \\
adj. $R^{2}(\%)$ & 0.7 & 1.3 & 1.3 \\
\hline \hline
\end{tabular}

Source: Authors' calculations with data from Statistiska Centralbyrån (SCB) and Swedish Interdisciplinary Panel (SIP). Standard errors, clustered at the County of Birth x Year of Birth level, in parentheses. All models shown control for county-specific linear trends and Countyof-Birth and Year-of-Birth Fixed Effects. Where indicated, the models control for the individual's gender, years of education (except when this is the outcome), linear and squared age of the mother at the individual's birth, and parental educational achievement. Interactions of the vector of controls with the pre-vaccine incidence rate at the county level are included only in model (3) for each outcome. Inclusion in the models is conditional on individuals' survival up to age 45 .

${ }^{*} p<0.05,{ }^{* *} p<0.01,{ }^{* * *} p<0.001$ 
Appendix 4: Robustness Check: Main Model with $H^{\text {pre }}$ redefined as a 20-year average (1937-1956) of Polio Incidence

\begin{tabular}{lccc}
\hline \hline & $\ln ($ Avg. Inc. 35-45) & \\
& $(1)$ & $(2)$ & $(3)$ \\
\hline$H^{\text {pre }} \cdot$ Post & -0.00374 & $-0.00466^{*}$ & $-0.00481^{*}$ \\
& $(0.00230)$ & $(0.00201)$ & $(0.00208)$ \\
Controls & No & Yes & Yes \\
Interactions of Controls* $\left(H^{\text {pre }}\right)$ & No & No & Yes \\
\hline$N$ & $2,132,769$ & $2,132,769$ & $2,132,769$ \\
adj. $R^{2}(\%)$ & 28.8 & 40.0 & 40.0 \\
\hline \hline
\end{tabular}

Years of Education

\begin{tabular}{lccc} 
& $(1)$ & $(2)$ & $(3)$ \\
\hline$H^{\text {pre }} \cdot$ Post & 0.00674 & 0.00276 & 0.00159 \\
& $(0.00952)$ & $(0.00926)$ & $(0.00940)$ \\
Controls & No & Yes & Yes \\
Interactions of Controls* $\left(H^{\text {pre }}\right)$ & No & No & Yes \\
\hline$N$ & $2,132,769$ & $2,132,769$ & $2,132,769$ \\
adj. $R^{2}(\%)$ & 5.7 & 13.9 & 13.9 \\
\hline \hline
\end{tabular}

№ of Hospitalizations

(1) $\quad(2)$

\begin{tabular}{lccc} 
& $(1)$ & $(2)$ & $(3)$ \\
\hline$H^{\text {pre }} \cdot$ Post & 0.0297 & 0.0337 & 0.0346 \\
& $(0.0254)$ & $(0.0253)$ & $(0.0257)$ \\
Controls & No & Yes & Yes \\
Interactions of Controls* $\left(H^{\text {pre }}\right)$ & No & No & Yes \\
\hline$N$ & $1,430,424$ & $1,430,424$ & $1,430,424$ \\
adj. $R^{2}(\%)$ & 0.7 & 1.3 & 1.3 \\
\hline \hline
\end{tabular}

Source: Authors' calculations with data from Statistiska Centralbyrån (SCB) and Swedish Interdisciplinary Panel (SIP). Standard errors, clustered at the County of Birth x Year of Birth level, in parentheses. All models shown control for county-specific linear trends and Countyof-Birth and Year-of-Birth Fixed Effects. Where indicated, the models control for the individual's gender, years of education (except when this is the outcome), linear and squared age of the mother at the individual's birth, and parental educational achievement. Interactions of the vector of controls with the pre-vaccine incidence rate at the county level are included only in model (3) for each outcome. Inclusion in the models is conditional on individuals' survival up to age 45 .

${ }^{*} p<0.05,{ }^{* *} p<0.01,{ }^{* * *} p<0.001$ 
Appendix 5: Robustness Check: Main model including only counties with very high (top 5) and very low (bottom 5 ) incidence rates of polio

\begin{tabular}{lccc}
\hline \hline & & & \\
& $\ln ($ Avg. Inc. 35-45) & \\
& $(1)$ & $(2)$ & $(3)$ \\
\hline$H^{\text {pre }} \cdot$ Post & $-0.00665^{* *}$ & $-0.00762^{* * *}$ & $-0.00782^{* * *}$ \\
& $(0.00201)$ & $(0.00176)$ & $(0.00185)$ \\
Controls & No & Yes & Yes \\
Interactions of Controls* $\left(H^{\text {pre }}\right)$ & No & No & Yes \\
\hline$N$ & $1,012,052$ & $1,012,052$ & $1,012,052$ \\
adj. $R^{2}(\%)$ & 27.0 & 37.9 & 37.9 \\
\hline \hline & Years of Education & \\
& $(1)$ & $(2)$ & $(3)$ \\
\hline$H^{\text {pre }} \cdot$ Post & 0.00441 & -0.00333 & -0.00501 \\
Controls & $(0.00872)$ & $(0.00874)$ & $(0.00898)$ \\
Interactions of Controls* $\left(H^{\text {pre }}\right)$ & No & Yes & Yes \\
\hline$N$ & No & No & Yes \\
adj. $R^{2}(\%)$ & $1,012,052$ & $1,012,052$ & $1,012,052$ \\
\hline \hline
\end{tabular}

\section{№ of Hospitalizations}

(1)

$(2)$

\begin{tabular}{lccc}
\hline$H^{\text {pre }} \cdot$ Post & $0.0633^{* *}$ & $0.0680^{* *}$ & $0.0663^{* *}$ \\
& $(0.0244)$ & $(0.0240)$ & $(0.0243)$ \\
Controls & No & Yes & Yes \\
Interactions of Controls* $\left(H^{\text {pre }}\right)$ & No & No & Yes \\
\hline$N$ & 683,678 & 683,678 & 683,678 \\
adj. $R^{2}(\%)$ & 0.6 & 1.3 & 1.3 \\
\hline \hline
\end{tabular}

Source: Authors' calculations with data from Statistiska Centralbyrån (SCB) and Swedish Interdisciplinary Panel (SIP). Standard errors, clustered at the County of Birth x Year of Birth level, in parentheses. All models shown control for county-specific linear trends and Countyof-Birth and Year-of-Birth Fixed Effects. Where indicated, the models control for the individual's gender, years of education (except when this is the outcome), linear and squared age of the mother at the individual's birth, and parental educational achievement. Interactions of the vector of controls with the pre-vaccine incidence rate at the county level are included only in model (3) for each outcome. Inclusion in the models is conditional on individuals' survival up to age 45 . The counties with the highest pre-vaccine incidence rate of polio were Stockholm Län, Uppsala Län, Kalmar Län, Gotlands Län, and Jämtlands Län, and those with the lowest rates were Jönköpings Län, Göteborgs och Bohus Län, Västmanlands Län, Västerbottens Län, Norrbottens Län. Only individuals born in these counties were included in this robustness check.

${ }^{*} p<0.05,{ }^{* *} p<0.01,{ }^{* * *} p<0.001$ 
Appendix 6: Robustness Check: Basic Pre-Post Analysis, dropping $H^{\text {pre }}$ from Main Model Specification.

\begin{tabular}{|c|c|c|c|}
\hline \multicolumn{4}{|c|}{$\ln ($ Avg. Inc. 35-45) } \\
\hline & $(1)$ & $(2)$ & $(3)$ \\
\hline \multirow[t]{2}{*}{ Post } & $1.783^{* * *}$ & $0.187^{* * *}$ & $0.187^{* * *}$ \\
\hline & $(0.0146)$ & $(0.0104)$ & $(0.0104)$ \\
\hline Controls & No & Yes & Yes \\
\hline Interactions of Controls* (Post) & No & No & Yes \\
\hline$N$ & $2,132,769$ & $2,132,769$ & $2,132,769$ \\
\hline adj. $R^{2}(\%)$ & 28.8 & 39.6 & 39.6 \\
\hline
\end{tabular}

Years of Education

\begin{tabular}{lccc} 
& $(1)$ & $(2)$ & $(3)$ \\
\hline Post & $1.749^{* * *}$ & $0.418^{* * *}$ & $0.418^{* * *}$ \\
& $(0.0549)$ & $(0.0191)$ & $(0.0191)$ \\
Controls & No & Yes & Yes \\
Interactions of Controls* ${ }^{*}$ Post) & No & No & Yes \\
\hline$N$ & $2,132,769$ & $2,132,769$ & $2,132,769$ \\
adj. $R^{2}(\%)$ & 5.7 & 13.7 & 13.7 \\
\hline \hline
\end{tabular}

\section{№ of Hospitalizations}

(1)

$(2)$

\begin{tabular}{lccc}
\hline Post & $-2.414^{* * *}$ & $-0.344^{* * *}$ & $-0.343^{* * *}$ \\
& $(0.142)$ & $(0.0308)$ & $(0.0308)$ \\
Controls & No & Yes & Yes \\
Interactions of Controls* ${ }^{*}$ Post) & No & No & Yes \\
\hline$N$ & $1,430,424$ & $1,430,424$ & $1,430,424$ \\
adj. $R^{2}(\%)$ & 0.7 & 1.2 & 1.2 \\
\hline \hline
\end{tabular}

Source: Authors' calculations with data from Statistiska Centralbyrån (SCB) and Swedish Interdisciplinary Panel (SIP). Standard errors, clustered at the County of Birth x Year of Birth level, in parentheses. All models shown control for county-specific linear trends and Countyof-Birth Fixed Effects. Where indicated, the models control for the individual's gender, years of education (except when this is the outcome), linear and squared age of the mother at the individual's birth, and parental educational achievement. Interactions of the vector of controls with the treatment indicator at the county level are included only in model (3) for each outcome. Inclusion in the models is conditional on individuals' survival up to age 45 . Please note that the results of this simple model are heavily affected by the exclusion of $H^{\text {pre }}$ and the necessary and subsequent exclusion of the Year-of-Birth fixed effects to avoid collinearity issues. These results are for comparison only and do not reflect the main analysis of our paper.

${ }^{*} p<0.05,{ }^{* *} p<0.01,{ }^{* * *} p<0.001$ 
Appendix 7: Robustness Check: Using Days of Hospitalization instead of Number of Hospitalizations. Main model results and by-gender results.

\begin{tabular}{lccc}
\hline \hline \multicolumn{4}{c}{ Days of Hospitalization: Main Model Results } \\
& $(1)$ & $(2)$ & $(3)$ \\
\hline$H^{\text {pre }} \cdot$ Post & $0.976^{* *}$ & $0.992^{* *}$ & $0.960^{*}$ \\
& $(0.360)$ & $(0.358)$ & $(0.375)$ \\
Controls & No & Yes & Yes \\
Interactions of Controls $\times\left(H^{\text {pre }}\right)$ & No & No & Yes \\
\hline$N$ & $1,430,424$ & $1,430,424$ & $1,430,424$ \\
adj. $R^{2}(\%)$ & 0.1 & 0.5 & 0.5 \\
\hline \hline
\end{tabular}

Days of Hospitalization: By-gender results

\begin{tabular}{lccc} 
Men $(N=629,521)$ & & \\
\hline$H^{\text {pre }} \cdot$ Post & 0.345 & 0.362 & 0.408 \\
& $(0.548)$ & $(0.548)$ & $(0.573)$ \\
Controls & No & Yes & Yes \\
Interactions of Controls $\times\left(H^{\text {pre }}\right)$ & No & No & Yes \\
\hline adj. $R^{2}(\%)$ & 0.1 & 0.4 & 0.4 \\
\hline & & & \\
Women $(N=800,902)$ & & & $1.391^{* *}$ \\
\hline$H^{\text {pre }} \cdot$ Post & $1.439^{* * *}$ & $1.460^{* * *}$ & $(0.436)$ \\
& $(0.428)$ & $(0.420)$ & Yes \\
Controls & No & Yes & Yes \\
Interactions of Controls $\times\left(H^{\text {pre }}\right)$ & No & No & 0.6 \\
\hline adj. $R^{2}(\%)$ & 0.2 & 0.6 & \\
\hline \hline
\end{tabular}

Source: Authors' calculations with data from Statistiska Centralbyrån (SCB) and Swedish Interdisciplinary Panel (SIP). Standard errors, clustered at the County of Birth x Year of Birth level, in parentheses. All models shown control for county-specific linear trends and Countyof-Birth Fixed Effects. Where indicated, the models control for the individual's gender (except for the by-gender results), years of education, linear and squared age of the mother at the individual's birth, and parental educational achievement. Interactions of the vector of controls with the pre-vaccine incidence rate at the county level are included only in model (3) for each outcome. Inclusion in the models is conditional on individuals' survival up to age 45 . ${ }^{*} p<0.05,{ }^{* *} p<0.01,{ }^{* * *} p<0.001$ 
Appendix 8: Robustness Check: Main Model using a dichotomous definition of $H^{\text {pre }}$ instead of a continuous one.

\begin{tabular}{|c|c|c|c|}
\hline \multicolumn{4}{|c|}{$\ln ($ Avg. Inc. 35-45) } \\
\hline & (1) & $(2)$ & (3) \\
\hline \multirow[t]{2}{*}{$H^{\text {pre }} \cdot$ Post } & $-0.0118^{* *}$ & $-0.0132^{* * *}$ & $-0.0135^{* * *}$ \\
\hline & $(0.00391)$ & $(0.00328)$ & $(0.00345)$ \\
\hline Controls & No & Yes & Yes \\
\hline Interactions of Controls* $\left(H^{\text {pre }}\right)$ & No & No & Yes \\
\hline$N$ & $2,132,769$ & $2,132,769$ & $2,132,769$ \\
\hline adj. $R^{2}(\%)$ & 28.8 & 40.0 & 40.0 \\
\hline
\end{tabular}

Years of Education

\begin{tabular}{lccc} 
& $(1)$ & $(2)$ & $(3)$ \\
\hline$H^{\text {pre }} \cdot$ Post & 0.00145 & -0.0120 & -0.0139 \\
& $(0.0161)$ & $(0.0165)$ & $(0.0167)$ \\
Controls & No & Yes & Yes \\
Interactions of Controls* $\left(H^{\text {pre }}\right)$ & No & No & Yes \\
\hline$N$ & $2,132,769$ & $2,132,769$ & $2,132,769$ \\
adj. $R^{2}(\%)$ & 5.7 & 13.9 & 13.9 \\
\hline \hline
\end{tabular}

№ of Hospitalizations

(1)

\begin{tabular}{lccc} 
& $(1)$ & $(2)$ & $(3)$ \\
\hline$H^{\text {pre }} \cdot$ Post & $0.114^{*}$ & $0.117^{* *}$ & $0.120^{* *}$ \\
& $(0.0453)$ & $(0.0448)$ & $(0.0460)$ \\
Controls & No & Yes & Yes \\
Interactions of Controls* $\left(H^{\text {pre }}\right)$ & No & No & Yes \\
\hline$N$ & $1,430,424$ & $1,430,424$ & $1,430,424$ \\
adj. $R^{2}(\%)$ & 0.7 & 1.3 & 1.3 \\
\hline \hline
\end{tabular}

Source: Authors' calculations with data from Statistiska Centralbyrån (SCB) and Swedish Interdisciplinary Panel (SIP). Standard errors, clustered at the County of Birth x Year of Birth level, in parentheses. All models shown control for county-specific linear trends and Countyof-Birth and Year-of-Birth Fixed Effects. Where indicated, the models control for the individual's gender, years of education (except when this is the outcome), linear and squared age of the mother at the individual's birth, and parental educational achievement. Interactions of the vector of controls with the pre-vaccine incidence rate at the county level are included only in model (3) for each outcome. Inclusion in the models is conditional on individuals' survival up to age 45. The dichotomous version of $H^{\text {pre }}$ was defined as taking the value of one if the county of birth had a pre-vaccine incidence rate that was over the mean of the continuous variable and zero otherwise.

${ }^{*} p<0.05,{ }^{* *} p<0.01,{ }^{* * *} p<0.001$ 
Appendix 9: Robustness Check: Main Model excluding partially exposed cohorts (1947-1957).

\begin{tabular}{|c|c|c|c|}
\hline \multicolumn{4}{|c|}{$\ln ($ Avg. Inc. 35-45) } \\
\hline & (1) & (2) & (3) \\
\hline \multirow[t]{2}{*}{$H^{p r e} \cdot$ Post } & -0.00916 & $-0.0104^{*}$ & $-0.00976^{*}$ \\
\hline & $(0.00594)$ & $(0.00481)$ & $(0.00484)$ \\
\hline \multirow{2}{*}{$\begin{array}{l}\text { Controls } \\
\text { Interactions of Controls* }\left(H^{p r e}\right)\end{array}$} & No & Yes & Yes \\
\hline & No & No & Yes \\
\hline \multirow{2}{*}{$\begin{array}{l}N \\
\text { adj. } R^{2}(\%) \\
\end{array}$} & $1,229,505$ & $1,229,505$ & $1,229,505$ \\
\hline & 37.8 & 47.2 & 47.2 \\
\hline \multicolumn{4}{|c|}{ Years of Education } \\
\hline & (1) & (2) & (3) \\
\hline$H^{p r e} \cdot$ Post & $\begin{array}{l}-0.0239 \\
(0.0203)\end{array}$ & $\begin{array}{l}-0.0388 \\
(0.0228)\end{array}$ & $\begin{array}{l}-0.0393 \\
(0.0232)\end{array}$ \\
\hline Controls & No & Yes & Yes \\
\hline Interactions of Controls* $\left(H^{p r e}\right)$ & No & No & Yes \\
\hline$N$ & $1,229,505$ & $1,229,505$ & $1,229,505$ \\
\hline adj. $R^{2}(\%)$ & 8.5 & 16.5 & 16.5 \\
\hline
\end{tabular}

№ of Hospitalizations

\begin{tabular}{lccc} 
& $(1)$ & $(2)$ & $(3)$ \\
\hline$H^{\text {pre }} \cdot$ Post & 0.116 & 0.118 & 0.120 \\
& $(0.0726)$ & $(0.0705)$ & $(0.0718)$ \\
Controls & No & Yes & Yes \\
Interactions of Controls* $\left(H^{\text {pre }}\right)$ & No & No & Yes \\
\hline$N$ & 851,751 & 851,751 & 851,751 \\
adj. $R^{2}(\%)$ & 1.1 & 1.6 & 1.6 \\
\hline \hline
\end{tabular}

Source: Authors' calculations with data from Statistiska Centralbyrån (SCB) and Swedish Interdisciplinary Panel (SIP). Standard errors, clustered at the County of Birth x Year of Birth level, in parentheses. All models shown control for county-specific linear trends and Countyof-Birth and Year-of-Birth Fixed Effects. Where indicated, the models control for the individual's gender, years of education (except when this is the outcome), linear and squared age of the mother at the individual's birth, and parental educational achievement. Interactions of the vector of controls with the pre-vaccine incidence rate at the county level are included only in model (3) for each outcome. Inclusion in the models is conditional on individuals' survival up to age 45 .

${ }^{*} p<0.05,{ }^{* *} p<0.01,{ }^{* * *} p<0.001$ 
Appendix 10: Robustness Check: Main Model excluding partially exposed cohorts in late childhood (ages 6-10 at the time of the vaccine introduction, 1947-1951 cohorts).

\begin{tabular}{lccc}
\hline \hline & ln $($ Avg. Inc. 35-45) & \\
& $(1)$ & $(2)$ & $(3)$ \\
\hline$H^{\text {pre }} \cdot$ Post & $-0.0111^{* * *}$ & $-0.0141^{* * *}$ & $-0.0142^{* * *}$ \\
& $(0.00309)$ & $(0.00248)$ & $(0.00267)$ \\
Controls & No & Yes & Yes \\
Interactions of Controls* $\left(H^{\text {pre }}\right)$ & No & No & Yes \\
\hline$N$ & $1,749,604$ & $1,749,604$ & $1,749,604$ \\
adj. $R^{2}(\%)$ & 30.8 & 41.2 & 41.2 \\
\hline \hline
\end{tabular}

Years of Education

\begin{tabular}{lccc} 
& $(1)$ & $(2)$ & $(3)$ \\
\hline$H^{\text {pre }} \cdot$ Post & 0.0176 & -0.000303 & -0.00180 \\
& $(0.0133)$ & $(0.0146)$ & $(0.0149)$ \\
Controls & No & Yes & Yes \\
Interactions of Controls* $\left(H^{\text {pre }}\right)$ & No & No & Yes \\
\hline$N$ & $1,749,604$ & $1,749,604$ & $1,749,604$ \\
adj. $R^{2}(\%)$ & 6.5 & 14.9 & 14.9 \\
\hline \hline
\end{tabular}

\section{No of Hospitalizations}

(1)

$(2)$

\begin{tabular}{lccc}
\hline$H^{\text {pre }} \cdot$ Post & $0.0974^{* *}$ & $0.107^{* *}$ & $0.110^{* *}$ \\
& $(0.0344)$ & $(0.0330)$ & $(0.0352)$ \\
Controls & No & Yes & Yes \\
Interactions of Controls* $\left(H^{\text {pre }}\right)$ & No & No & Yes \\
\hline$N$ & $1,179,724$ & $1,179,724$ & $1,179,724$ \\
adj. $R^{2}(\%)$ & 0.8 & 1.4 & 1.4 \\
\hline \hline
\end{tabular}

Source: Authors' calculations with data from Statistiska Centralbyrån (SCB) and Swedish Interdisciplinary Panel (SIP). Standard errors, clustered at the County of Birth x Year of Birth level, in parentheses. All models shown control for county-specific linear trends and Countyof-Birth and Year-of-Birth Fixed Effects. Where indicated, the models control for the individual's gender, years of education (except when this is the outcome), linear and squared age of the mother at the individual's birth, and parental educational achievement. Interactions of the vector of controls with the pre-vaccine incidence rate at the county level are included only in model (3) for each outcome. Inclusion in the models is conditional on individuals' survival up to age 45 .

${ }^{*} p<0.05,{ }^{* *} p<0.01,{ }^{* * *} p<0.001$ 
Appendix 11: Robustness Check: Main Model excluding the cohorts born during World War II (1939-1945).

\begin{tabular}{lccc}
\hline \hline & $\ln ($ Avg. Inc. 35-45) & \\
& $(1)$ & $(2)$ & $(3)$ \\
\hline$H^{\text {pre }} \cdot$ Post & $-0.00848^{*}$ & $-0.00857^{* * *}$ & $-0.00895^{* * *}$ \\
& $(0.00365)$ & $(0.00251)$ & $(0.00261)$ \\
Controls & No & Yes & Yes \\
Interactions of Controls* $\left(H^{\text {pre }}\right)$ & No & No & Yes \\
\hline$N 1,878,888$ & $1,878,888$ & $1,878,888$ & \\
adj. $R^{2}(\%)$ & 19.3 & 31.0 & 31.0 \\
\hline \hline
\end{tabular}

Years of Education

\begin{tabular}{lccc} 
& $(1)$ & $(2)$ & $(3)$ \\
\hline$H^{\text {pre }} \cdot$ Post & 0.00514 & -0.0144 & -0.0158 \\
& $(0.0159)$ & $(0.0162)$ & $(0.0163)$ \\
Controls & No & Yes & Yes \\
Interactions of Controls* $\left(H^{\text {pre }}\right)$ & No & No & Yes \\
\hline$N$ & $1,878,888$ & $1,878,888$ & $1,878,888$ \\
adj. $R^{2}(\%)$ & 3.3 & 12.4 & 12.4 \\
\hline \hline
\end{tabular}

№ of Hospitalizations

(1)

\begin{tabular}{lccc} 
& $(1)$ & $(2)$ & $(3)$ \\
\hline$H^{\text {pre }} \cdot$ Post & 0.0468 & 0.0469 & 0.0484 \\
& $(0.0382)$ & $(0.0372)$ & $(0.0378)$ \\
Controls & No & Yes & Yes \\
Interactions of Controls* $\left(H^{\text {pre }}\right)$ & No & No & Yes \\
\hline$N$ & $1,242,871$ & $1,242,871$ & $1,242,871$ \\
adj. $R^{2}(\%)$ & 0.4 & 1.0 & 1.0 \\
\hline \hline
\end{tabular}

Source: Authors' calculations with data from Statistiska Centralbyrån (SCB) and Swedish Interdisciplinary Panel (SIP). Standard errors, clustered at the County of Birth x Year of Birth level, in parentheses. All models shown control for county-specific linear trends and Countyof-Birth and Year-of-Birth Fixed Effects. Where indicated, the models control for the individual's gender, years of education (except when this is the outcome), linear and squared age of the mother at the individual's birth, and parental educational achievement. Interactions of the vector of controls with the pre-vaccine incidence rate at the county level are included only in model (3) for each outcome. Inclusion in the models is conditional on individuals' survival up to age 45 .

${ }^{*} p<0.05,{ }^{* *} p<0.01,{ }^{* * *} p<0.001$ 
Appendix 12: Robustness Check: Main Model excluding the cohort born during the last polio epidemic (1953).

\begin{tabular}{|c|c|c|c|}
\hline \multicolumn{4}{|c|}{$\ln ($ Avg. Inc. 35-45) } \\
\hline$H^{\text {pre }} \cdot$ Post & $\begin{array}{c}-0.00765^{* * *} \\
(0.00211)\end{array}$ & $\begin{array}{c}-0.00849^{* * *} \\
(0.00173)\end{array}$ & $\begin{array}{c}-0.00869^{* * *} \\
(0.00187)\end{array}$ \\
\hline Controls & No & Yes & Yes \\
\hline Interactions of Controls* $\left(H^{\text {pre }}\right)$ & No & No & Yes \\
\hline$N 2,047,326$ & $2,047,326$ & $2,047,326$ & \\
\hline adj. $R^{2}(\%)$ & 29.6 & 40.7 & 40.7 \\
\hline \multicolumn{4}{|c|}{ Years of Education } \\
\hline$H^{\text {pre }} \cdot$ Post & $\begin{array}{c}0.00123 \\
(0.00853)\end{array}$ & $\begin{array}{l}-0.00585 \\
(0.00885)\end{array}$ & $\begin{array}{c}-0.00696 \\
(0.00901)\end{array}$ \\
\hline Controls & No & Yes & Yes \\
\hline Interactions of Controls* $\left(H^{\text {pre }}\right)$ & No & No & Yes \\
\hline$N$ & $2,047,326$ & $2,047,326$ & $2,047,326$ \\
\hline adj. $R^{2}(\%)$ & 5.8 & 14.1 & 14.1 \\
\hline \multicolumn{4}{|c|}{ No of Hospitalizations } \\
\hline$H^{\text {pre }} \cdot$ Post & $\begin{array}{l}0.0687^{* *} \\
(0.0247)\end{array}$ & $\begin{array}{c}0.0713^{* *} \\
(0.0244)\end{array}$ & $\begin{array}{c}0.0727^{* *} \\
(0.0252)\end{array}$ \\
\hline Controls & No & Yes & Yes \\
\hline Interactions of Controls* $\left(H^{\text {pre }}\right)$ & No & No & Yes \\
\hline$N$ & $1,376,957$ & $1,376,957$ & $1,376,957$ \\
\hline adj. $R^{2}(\%)$ & 0.7 & 1.3 & 1.3 \\
\hline \multicolumn{4}{|c|}{$\begin{array}{l}\text { Source: Authors' calculations with data from Statistiska Centralbyrån (SCB) and Swedish In- } \\
\text { terdisciplinary Panel (SIP). Standard errors, clustered at the County of Birth x Year of Birth } \\
\text { level, in parentheses. All models shown control for county-specific linear trends and County- } \\
\text { of-Birth and Year-of-Birth Fixed Effects. Where indicated, the models control for the indi- } \\
\text { vidual's gender, years of education (except when this is the outcome), linear and squared age } \\
\text { of the mother at the individual's birth, and parental educational achievement. Interactions of } \\
\text { the vector of controls with the pre-vaccine incidence rate at the county level are included only } \\
\text { in model (3) for each outcome. Inclusion in the models is conditional on individuals' survival } \\
\text { up to age } 45 \text {. } \\
{ }^{*} p<0.05,{ }^{* *} p<0.01,{ }^{* * *} p<0.001\end{array}$} \\
\hline
\end{tabular}


Appendix 13: Robustness Check: Main Model with Average Income divided by ages 35-40 and $40-$ 45.

\begin{tabular}{|c|c|c|c|}
\hline \multicolumn{4}{|c|}{$\ln ($ Avg. Inc. 35-40) } \\
\hline$H^{\text {pre }} \cdot$ Post & $\begin{array}{c}-0.00825^{* *} \\
(0.00250)\end{array}$ & $\begin{array}{c}-0.00953^{* * *} \\
(0.00212)\end{array}$ & $\begin{array}{c}-0.00949^{* * *} \\
(0.00222)\end{array}$ \\
\hline Controls & No & Yes & Yes \\
\hline Interactions of Controls* $\left(H^{\text {pre }}\right)$ & No & No & Yes \\
\hline$N$ & $2,126,354$ & $2,126,354$ & $2,126,354$ \\
\hline adj. $R^{2}(\%)$ & 32.2 & 42.7 & 42.7 \\
\hline & \multicolumn{2}{|c|}{$\ln (A v g$. Inc. 40-45) } & $(3)$ \\
\hline$H^{\text {pre }} \cdot$ Post & $\begin{array}{c}-0.00676^{* *} \\
(0.00227)\end{array}$ & $\begin{array}{c}-0.00797^{* * *} \\
(0.00193)\end{array}$ & $\begin{array}{c}-0.00847^{* * *} \\
(0.00209)\end{array}$ \\
\hline Controls & No & Yes & Yes \\
\hline Interactions of Controls* $\left(H^{\text {pre }}\right)$ & No & No & Yes \\
\hline$N$ & $2,120,155$ & $2,120,155$ & $2,120,155$ \\
\hline adj. $R^{2}(\%)$ & 22.4 & 32.5 & 32.5 \\
\hline \multicolumn{4}{|c|}{$\begin{array}{l}\text { Source: Authors' calculations with data from Statistiska Centralbyrån (SCB) and Swedish In- } \\
\text { terdisciplinary Panel (SIP). Standard errors, clustered at the County of Birth x Year of Birth } \\
\text { level, in parentheses. All models shown control for county-specific linear trends and County- } \\
\text { of-Birth and Year-of-Birth Fixed Effects. Where indicated, the models control for the indi- } \\
\text { vidual's gender, years of education (except when this is the outcome), linear and squared age } \\
\text { of the mother at the individual's birth, and parental educational achievement. Interactions of } \\
\text { the vector of controls with the pre-vaccine incidence rate at the county level are included only } \\
\text { in model (3) for each outcome. Inclusion in the models is conditional on individuals' survival } \\
\text { up to age } 45 \text {. } \\
{ }^{*} p<0.05,{ }^{* *} p<0.01,{ }^{* * *} p<0.001\end{array}$} \\
\hline
\end{tabular}


Appendix 14: Robustness Check: Placebo Test with different starting cohort of the treated group (1942).

\begin{tabular}{lccc}
\hline \hline & \multicolumn{4}{c}{} & \\
& $\ln ($ Avg. Inc. 35-45) & \\
& $(1)$ & $(2)$ & $(3)$ \\
\hline$H^{\text {pre }} \cdot$ Post & $-0.00690^{*}$ & $-0.00811^{* *}$ & $-0.00848^{* *}$ \\
& $(0.00329)$ & $(0.00289)$ & $(0.00305)$ \\
Controls & No & Yes & Yes \\
Interactions of Controls* $\left(H^{\text {pre }}\right)$ & No & No & Yes \\
\hline$N$ & $2,132,769$ & $2,132,769$ & $2,132,769$ \\
adj. $R^{2}(\%)$ & 28.8 & 40.0 & 40.0 \\
\hline \hline
\end{tabular}

Years of Education

\begin{tabular}{lccc} 
& $(1)$ & $(2)$ & $(3)$ \\
\hline$H^{\text {pre }} \cdot$ Post & 0.0142 & 0.00168 & -0.0000144 \\
& $(0.0124)$ & $(0.0122)$ & $(0.0122)$ \\
Controls & No & Yes & Yes \\
Interactions of Controls* $\left(H^{\text {pre }}\right)$ & No & No & Yes \\
\hline$N$ & $2,132,769$ & $2,132,769$ & $2,132,769$ \\
adj. $R^{2}(\%)$ & 5.7 & 13.9 & 13.9 \\
\hline \hline
\end{tabular}

№ of Hospitalizations

(1) $\quad(2)$

\begin{tabular}{lccc} 
& $(1)$ & $(2)$ & $(3)$ \\
\hline$H^{\text {pre }} \cdot$ Post & 0.0320 & 0.0340 & 0.0365 \\
& $(0.0290)$ & $(0.0290)$ & $(0.0302)$ \\
Controls & No & Yes & Yes \\
Interactions of Controls* $\left(H^{\text {pre }}\right)$ & No & No & Yes \\
\hline$N$ & $1,430,424$ & $1,430,424$ & $1,430,424$ \\
adj. $R^{2}(\%)$ & 0.7 & 1.3 & 1.3 \\
\hline \hline
\end{tabular}

Source: Authors' calculations with data from Statistiska Centralbyrån (SCB) and Swedish Interdisciplinary Panel (SIP). Standard errors, clustered at the County of Birth x Year of Birth level, in parentheses. All models shown control for county-specific linear trends and Countyof-Birth and Year-of-Birth Fixed Effects. Where indicated, the models control for the individual's gender, years of education (except when this is the outcome), linear and squared age of the mother at the individual's birth, and parental educational achievement. Interactions of the vector of controls with the pre-vaccine incidence rate at the county level are included only in model (3) for each outcome. Inclusion in the models is conditional on individuals' survival up to age 45 .

${ }^{*} p<0.05,{ }^{* *} p<0.01,{ }^{* * *} p<0.001$ 
Appendix 15: Robustness Check: Placebo Test with different starting cohort of the treated group (1952).

\begin{tabular}{|c|c|c|c|}
\hline \multicolumn{4}{|c|}{$\ln ($ Avg. Inc. 35-45) } \\
\hline & (1) & $(2)$ & $(3)$ \\
\hline \multirow[t]{2}{*}{$H^{\text {pre }} \cdot$ Post } & -0.00355 & $-0.00574^{* *}$ & $-0.00561^{* *}$ \\
\hline & $(0.00329)$ & $(0.00289)$ & $(0.00305)$ \\
\hline Controls & No & Yes & Yes \\
\hline Interactions of Controls* $\left(H^{p r e}\right)$ & No & No & Yes \\
\hline$N$ & $2,132,769$ & $2,132,769$ & $2,132,769$ \\
\hline adj. $R^{2}(\%)$ & 28.8 & 40.0 & 40.0 \\
\hline
\end{tabular}

Years of Education

\begin{tabular}{lccc} 
& $(1)$ & $(2)$ & $(3)$ \\
\hline$H^{\text {pre }} \cdot$ Post & 0.0149 & 0.00329 & 0.00295 \\
& $(0.0124)$ & $(0.0122)$ & $(0.0122)$ \\
Controls & No & Yes & Yes \\
Interactions of Controls* $\left(H^{\text {pre }}\right)$ & No & No & Yes \\
\hline$N$ & $2,132,769$ & $2,132,769$ & $2,132,769$ \\
adj. $R^{2}(\%)$ & 5.7 & 13.9 & 13.9 \\
\hline \hline
\end{tabular}

№ of Hospitalizations

(1) $\quad(2)$

\begin{tabular}{lccc} 
& $(1)$ & $(2)$ & $(3)$ \\
\hline$H^{\text {pre }} \cdot$ Post & 0.0304 & 0.0377 & 0.0378 \\
& $(0.0290)$ & $(0.0290)$ & $(0.0302)$ \\
Controls & No & Yes & Yes \\
Interactions of Controls* $\left(H^{\text {pre }}\right)$ & No & No & Yes \\
\hline$N$ & $1,430,424$ & $1,430,424$ & $1,430,424$ \\
adj. $R^{2}(\%)$ & 0.7 & 1.3 & 1.3 \\
\hline \hline
\end{tabular}

Source: Authors' calculations with data from Statistiska Centralbyrån (SCB) and Swedish Interdisciplinary Panel (SIP). Standard errors, clustered at the County of Birth x Year of Birth level, in parentheses. All models shown control for county-specific linear trends and Countyof-Birth and Year-of-Birth Fixed Effects. Where indicated, the models control for the individual's gender, years of education (except when this is the outcome), linear and squared age of the mother at the individual's birth, and parental educational achievement. Interactions of the vector of controls with the pre-vaccine incidence rate at the county level are included only in model (3) for each outcome. Inclusion in the models is conditional on individuals' survival up to age 45 .

${ }^{*} p<0.05,{ }^{* *} p<0.01,{ }^{* * *} p<0.001$ 
Appendix 16: Exploring the Possibility of Compensatory Behavior among Polio Survivors: Main Model and Scarring Models with Dichotomous Occupation at age 45 ( $1=$ manual, $0=$ non manual) as an outcome.

Panel 1: Manual Occupation at Age 45 (reporting odds ratios)

\begin{tabular}{lccc} 
& $(1)$ & $(2)$ & $(3)$ \\
\hline$H^{\text {pre }} \cdot$ Post & 1.010638 & 1.018823 & 1.012811 \\
& $(0.00923)$ & $(0.0152)$ & $(0.00993)$ \\
Controls & No & Yes & Yes \\
Interactions of Controls* $\left(H^{\text {pre }}\right)$ & No & No & Yes \\
\hline$N$ & $2,013,807$ & $2,013,807$ & $2,013,807$ \\
Pseudo $R^{2}(\%)$ & 1.13 & 9.45 & 9.47 \\
\hline \hline
\end{tabular}

Panel 2: Scarring Effect by year of exposure to the 1953 Outbreak

Outcome variable: Manual Occupation at Age 45

Odds Ratio

\begin{tabular}{lc}
\hline Third Year of Life & 1.000769 \\
(Age 2) & $(0.000468)$ \\
& \\
Second Year of Life & 1.000823 \\
(Age 1) & $(0.000443)$ \\
& \\
Year of Birth & 1.000861 \\
(Age 0$)$ & $(0.000537)$ \\
& \\
\hline$N$ & 478,236 \\
adj. $R^{2}(\%)$ & 2.7 \\
\hline \hline
\end{tabular}

Panel 3: Scarring Effect. Comparing only 1952 and 1954 cohorts

Outcome variable: Manual Occupation at Age 45

Odds Ratio

$\begin{array}{cc}\text { Scarring effect } & 1.000222 \\ & (0.000255)\end{array}$

\begin{tabular}{l}
\hline$N$ \\
adj. $R^{2}(\%)$ \\
\hline \hline Source: Authors' calculations with data from Statistiska Centralbyrån (SCB) and Swedish In- \\
terdisciplinary Panel (SIP). Standard errors, clustered at the County of Birth x Year of Birth \\
level, in parentheses. All models shown control for county-specific linear trends and County- \\
of-Birth and Year-of-Birth Fixed Effects. Where indicated, the models control for the indi- \\
vidual's gender, years of education (except when this is the outcome), linear and squared age \\
of the mother at the individual's birth, and parental educational achievement. Interactions of \\
the vector of controls with the pre-vaccine incidence rate at the county level are included only \\
in model (3) for in panel 1. Inclusion in the models in panel 1 is conditional on individuals' \\
survival up to age 45. Inclusion in the models in panel 2 is conditional on being born between \\
1951 and 1956 and survival up to age 45 . Inclusion in the model in panel 3 is conditional on \\
being born in either 1952 or 1954 and survival up to age 45. \\
${ }^{*} p<0.05,{ }^{* *} p<0.01,{ }^{* * *} p<0.001$
\end{tabular}

